\title{
Flooding and land use change in Jambi Province, Sumatra: integrating local knowledge and scientific inquiry
}

\author{
$\underline{\text { Jennifer Merten }}^{1,2}{ }^{\text {Christian Stiegler }}{ }^{3}$, Nina Hennings $^{4}, \underline{\text { Edwine S. Purnama }}^{5}$, Alexander Röll ${ }^{6}, \underline{\text { Herdhata Agusta }}^{7,8}$, Michaela A. $^{6}$

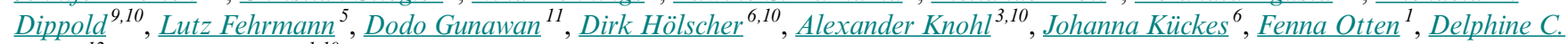 \\ $\underline{\text { Zemp }}^{12}$ and $\underline{\text { Heiko Faust }}^{1,10}$
}

\begin{abstract}
The rapid expansion of rubber and oil palm plantations in Jambi Province, Sumatra, Indonesia, is associated with largescale deforestation and the impairment of many ecosystem services. According to villagers' observations, this land use change has, together with climate change, led to an increase in the magnitude and frequency of river flood events, which constrain village and plantation development. Based on this empirical societal problem, we investigate whether we can find measurable indications for the presumed linkages between land use change, climate change, and changing flooding regimes. We follow an explorative, bottom-up research approach that builds on a review of multidisciplinary datasets, integrating local ecological knowledge with scientific measurements from soil science, climatology, hydrology, and remote sensing. We found that water levels of one of the largest rivers in Jambi Province, the Tembesi, have increased significantly during the last two decades. Data of local and regional meteorological stations show that alterations in rainfall patterns may only partly explain these changes. Rather, increased soil densities and decreased water infiltration rates in monoculture plantations suggest an increase in surface runoff following forest conversion. Moreover, additional interview data reveal that an increasing encroachment of wetlands in Jambi Province may contribute to changes in local flooding regimes, as the construction of drainage and flood control infrastructure redistributes floodwater at the local scale. We conclude that changing flooding regimes are the result of multiple interacting social-ecological processes associated with the expansion of rubber and oil palm plantations in Jambi Province. Although ecohydrological changes are likely to contribute to an increase of flood occurrence, their social impacts are increasingly mediated through flood control infrastructure on industrial oil palm plantations.
\end{abstract}

Key Words: ecohydrology; flooding; global change; Indonesia; interdisciplinary analysis; land use conversion; local ecological knowledge; oil palm; rubber

\section{INTRODUCTION}

In the past, flooding occurred rarely. ... Back then, most people didn't plant oil palm, didn't plant rubber. ... It started, because the forest is already gone. That's why nowadays flooding occurs so often. ... For annual crops, if flooding occurs more often, that's a problem. ... [Sometimes] when the farmers had just planted the seedlings, then suddenly flooding occurred. (rubber farmer, Jambi, Sumatra, Indonesia)

In Southeast Asia, large areas of lowland forests have been converted to oil palm, rubber, and pulp wood plantations over the last decades (Hansen et al. 2013, Margono et al. 2014, Clough et al. 2016). For example, in 2015, oil palm plantations in Malaysia and Indonesia covered an area of 17 million ha (Chong et al. 2017). Such intense land use change is often followed by an impairment of ecohydrological functions (Bruijnzeel 2004, Bradshaw et al. 2007, Ellison et al. 2017). Several studies have recently started to connect the expansion of rubber and oil palm monoculture plantation systems with increases in the frequency and intensity of flooding.
The existing studies build on a variety of methodological approaches. Hydrological measurements showed that oil palm monoculture plantations may have low soil water infiltration rates (Tarigan et al. 2018) as a consequence of severe soil degradation and erosion (Guillaume et al. 2015, 2016). Particularly in combination with low evapotranspiration rates of young oil palm plantations this may increase surface run-off and the risk of flooding in oil palm dominated landscapes (Manoli et al. 2018, Tarigan et al. 2018). These findings also correspond with a timeseries analysis of streamflow data that found evidence for increasing streamflow through upstream land use conversion to rubber and oil palm plantations (Adnan and Atkinson 2011). Other approaches have built on spatial analyses and econometric modeling. For example, Tan-Soo et al. (2016) and Wells et al. (2016) found rubber and oil palm plantations to be spatially associated with reports of increasing flooding occurrence in Malaysia and Indonesia. Finally, a number of studies conducting qualitative social research present interview data from villagers across Indonesia who associated land use change, toward monoculture plantations, with increasing flood occurrence (Obidzinski et al. 2012, Larsen et al. 2014, Kelley and Prabowo 2019).

\footnotetext{
${ }^{1}$ University of Goettingen, Human Geography, Germany, ${ }^{2}$ Humboldt-Universität zu Berlin, Integrative Research Institute on Transformations of Human-Environment Systems (IRI THESys), Germany, ${ }^{3}$ University of Goettingen, Bioclimatology, Germany, ${ }^{4}$ University of Goettingen, Soil Science of Temperate Ecosystems, Germany, ${ }_{5}^{5}$ University of Goettingen, Forest Inventory and Remote Sensing, Germany, ${ }^{6}$ University of Goettingen, Tropical Silviculture and Forest Ecology, Germany, ${ }^{7}$ Bogor Agricultural University, Agronomy and Horticulture, Indonesia, ${ }^{8}$ Bogor Agricultural University, Surfactant and Bioenergy Research Center (SBRC), Indonesia, ${ }^{9}$ University of Goettingen, Biogeochemistry of Agroecosystems, Germany, ${ }^{10}$ University of Goettingen, Centre of Biodiversity and Sustainable Land Use (CBL), Germany, ${ }^{11}$ Agency for Meteorology, Climatology and Geophysics, Center of Climate Change Information, Jakarta, Indonesia, ${ }^{12}$ University of Goettingen, Biodiversity, Macroecology and Biogeography, Germany
} 
Such a linkage between the expansion of plantations and flooding was also observed by villagers in our study area in Jambi Province, Sumatra, as pointed out in the above quote from a smallholder farmer. In times of rapid land use change for global cash crop production, understanding such processes is of great relevance for the affected communities. Although the above-mentioned studies provide some evidence of changing flooding regimes due to plantation expansion, most of them present compartmentalized insights from single disciplines. A substantial gap in knowledge about the multiplicity of causal processes between land use change, climate change, and river water levels remains in our study region and beyond.

Establishing the linkage between land use change and flooding has been a long and contested endeavor among natural as well as social scientists (Calder and Aylward 2006, Bradshaw et al. 2007, van Dijk et al. 2009, Lele 2009). In public discourses, deforestation is often linked to an increase in the frequency and intensity of flooding. In fact, tree and forest removal is well known for raising the likelihood of floods, as decreasing evapotranspiration rates and decreasing water infiltration increase local surface runoff (Ellison et al. 2017). However, after deforestation, such processes may be reversed. Water infiltration rates may recover and evapotranspiration rates by planted tree species may then be as high as those of natural forests (Bruijnzeel 2004). Natural scientists have further cautioned that linkages between land use change and flooding regimes often depend upon the interaction of multiple, site-specific ecohydrological processes, including local climate change (Bradshaw et al. 2007, Alila et al. 2009, Locatelli and Vignola 2009, van Dijk et al. 2009, Tran et al. 2010, Pattison and Lane 2012). Social scientists, for their part, have warned that a generalization of the forest-flood linkage may result in policies with adverse social consequences, e.g., upstream forest dwellers being restricted in their land use activities and falsely blamed for causing downstream flooding (Saberwal 1998, Calder and Aylward 2006, Hofer and Messerli 2006). Moreover, they have pointed out that studies within the natural sciences often ignore the social and technical context that mediates flood impacts as well as response and feedback processes (Lele 2009, Di Baldassare et al. 2014).

Integrating local ecological knowledge into scientific analysis can address some of the above-mentioned uncertainties and risks when studying complex social-ecological phenomena (Pierotti and Wildcat 2000, Fabricius et al. 2006, Stringer and Reed 2007, Tengö et al. 2014, Leimona et al. 2015, Días et al. 2018). Such an integration of different knowledge sources may also enable research outcomes to be socially and practically more relevant in the local social context and is considered an important step toward democratizing explanations of environmental change (Forsyth 2003).

In this paper we aim to provide an integrated analysis of linkages between land use change, climate change, and flooding regimes by combining qualitative interview data on local ecological knowledge with scientific measurements. We examined multidisciplinary datasets to identify potential social-ecological processes that could explain the villagers' observations of increases in flood frequency and intensity following forest conversion in the Tembesi watershed in Jambi Province (Sumatra, Indonesia).
Our research objectives are the following: building on qualitative interviews, we (1) review villagers' observations of changes in patterns and intensity of flood events as well as their evaluations of changing environmental processes. We then (2) test whether the reported changes in flooding regimes are mirrored in available stream flow data from the Tembesi River. Building on the villagers' evaluations of the potential causes for changing flooding regimes, we test whether changes in climate and/or in land use can provide explanations for the observed changes. Therefore, we (3) analyze local precipitation patterns for changes over the last decades, and (4) compare hydraulic soil properties in different land use systems. More specifically, we quantify land use change in the Tembesi River watershed (1990-2013) and assess whether soil bulk densities (as an indicator of soil compaction), water infiltration capacities, and groundwater levels of oil palm and rubber plantations differ from forests and less intensively managed reference systems. Finally, based on villagers' specific concerns for land use change in wetland areas, we (5) investigate whether forest conversion in wetland areas has further contributed to an alteration of flooding regimes. To this aim, we analyze the land use history as well as land use characteristics of wetland areas, building on land use data (1990-2013) as well as on a comparison of qualitative case study data within the Tembesi watershed.

Finally, we integrate these multiple knowledge sources by discussing convergences, complementarities, and divergences among datasets. Although our study design was not a priori designed to answer questions related to flooding specifically, we show that an a posteriori analysis of different knowledge sources can be an important tool for interdisciplinary research. It can also provide a more complete analysis of the complex linkages between land use change and flooding.

\section{CONCEPTUAL FRAMEWORK}

Our research approach builds on the tradition of critical realist approaches in political ecology and sustainability sciences. These studies emphasize the need for problem-driven, bottom-up research approaches that integrate different knowledge sources to find locally framed explanations of environmental problems (Forsyth 2003, Walters and Vayda 2009, Lele and Kurien 2011, Thorén and Persson 2013, Ribot 2014).

Studies on flooding and flood impacts in the context of land use change are often dominated by accounts from the natural sciences. Changes in flooding regimes are mainly derived from direct ground-based measurements using water level or discharge data from flood gauges (e.g., MDID 1989, Yusop et al. 2007, Adnan and Atkinson 2011), or modeling exercises. Model inputs are typically based on direct field measurements of the different components of the hydrological cycle, such as soil surface runoff, infiltration rates, throughfall, or evapotranspiration rates (e.g., Manoli et al. 2018, Tarigan et al. 2018). Precipitation quantities are either obtained from satellite-derived precipitation and cloud cover estimates (Maggioni and Massari 2018), or based on combined field and satellite measurements (Kwak 2017). In recent years, satellite imagery has become a widely used tool for monitoring flood events on a large scale. However, optical-based satellite imagery has its limitations because of cloud cover, especially in the tropics (Ahamed and Bolten 2017, Ban et al. 2017, Adam et al. 2018, Notti et al. 2018). Typical indicators for 
changing flooding regimes include the number of days with extreme water levels or peak flows, average water level rise as an indicator for flash floods, average seasonal water levels, or shifts in seasonal water levels (Dang et al. 2011, Wang et al. 2015).

These approaches, however, have a number of limitations with regard to data availability and the integration of the human dimension. In the study of flooding regimes, local people's ecological knowledge may thus fruitfully complement scientific measurements. Local ecological knowledge (sometimes also referred to as traditional ecological knowledge) comprises three components of knowledge: observational knowledge, knowledge acquired through practical experience, and knowledge in the form of people's beliefs (Berkes et al. 2000). Such knowledge is acquired through personal empirical observation and interpretation of local ecosystems, and enriched and validated through exchange with other farmers and villagers (Berkes et al. 2000, Usher 2000, Houde 2007).

In particular, the integration of observational and practical local ecological knowledge may provide several benefits for establishing a link between land use change and flooding regimes. First, local ecological knowledge provides fine-grained information about ecosystems in areas where little scientific knowledge exists, such as rural Sumatra (Fabricius et al. 2006). A typical problem of scientific measurements is that field measurements are often only available at plot scale. On the other hand, modeling exercises conducted at larger scales often provide little information about factual changes in flooding regimes, e.g., at the village level. Integrating people's knowledge might also be useful for detecting environmental changes that are not immediately apparent in short-term scientific measurements as local people get to observe things more often, over longer periods, and in a wider variety of places (Usher 2000). Thereby it might draw attention to environmental change that otherwise would possibly not be studied. For example, Wells et al. (2016) integrated interview data with newspaper reports of flooding and watershed characteristics to show that flooding is far more widespread than reported in government assessments. Moreover, local ecological knowledge is considered to be holistic in nature, compared to scientific studies that are often compartmentalized (Pierotti and Wildcat 2000, Fabricius et al. 2006, Aikenhead and Ogawa 2007). Integrating local ecological knowledge in the study of land use change and flooding may thus enable more open research approaches, which could better account for multiple and interacting processes in the generation of flood events.

Second, both field measurements and modeling exercises often fail to adequately incorporate the human dimension of the problem, both with regard to defining what constitutes a problematic change in flooding as well as with regard to potential human influences on water flows (Lele 2009, Di Baldassare et al. 2014, Langill and Abizaid 2020). Lele and Kurien (2011) thus call for a shift from theory-driven to problem-driven, bottom-up research, to avoid research questions that are only determined by what the researcher is trained in. For example, by questioning what actually constitutes a "bad flood," Langill and Abizaid (2020) showed that studies of extreme floods within the natural sciences typically focused on unusually high floods. In their study, they showed that for a floodplain community in the Peruvian Amazon the timing and duration of flooding were in fact the most salient features of problematic floods. Existing studies connecting land use change in Indonesia and Malaysia to changing flooding regimes either investigated streamflow fluctuations independent of human evaluation (Adnan and Atkinson 2011) or looked at the number of flood events reported by newspapers and government assessments (Tan-Soo et al. 2016, Wells et al. 2016).

Integrating local ecological knowledge into the study of land use change and flooding may also help to draw attention to the social and technical context that mediates flood impacts. This integration may further contribute to an understanding of how changing flooding regimes may trigger people's response and feedback processes that shape water flows in turn (Lele 2009, Di Baldassare et al. 2014). For instance, Kelley and Prabowo (2019) use oral histories to reveal social transformation processes set in motion by changing flooding regimes. These transformation processes were shown to increase the people's systemic vulnerability to flooding as well as producing feedbacks of altering river flows.

Although multiple opportunities for integrating local knowledge and scientific measurements exist, the pitfalls of integration have also been discussed at length and, at times, in a controversial manner (Klubnikin et al. 2000, Pierotti and Wildcat 2000, Moller et al. 2004, Bohensky and Maru 2011, Persson et al. 2018). Similar to the integration of methods from qualitative social science and quantitative natural science, it has been pointed out that ontological and epistemological differences between knowledge sources may hinder output-oriented knowledge integration (Nadasdy 1999, Krüger et al. 2016, Thorén and Stahlhammer 2018). In particular, in-depth confrontations between different ontological understandings and assumptions, or critical engagements with other approaches for establishing scientific quality and validity of methods, are often limited by time constraints. Despite such concerns, we argue that more pragmatic approaches that foster interdisciplinary research are both possible and valuable. An important condition for overcoming challenges of integration is a common framing of the research problem. Several scholars have therefore recommended taking an empirical societal problem as a starting point of analysis, i.e., observations of increasing flood occurrence (Walters and Vayda 2009, Lele and Kurien 2011, Thorén and Persson 2013). Explanations from different disciplines and knowledge sources may then be reconciled by seeing each as partial, context-specific, and potentially fallible, but acknowledging that the combination of different sources may provide better understandings of environmental problems (Yeung 1997, Forsyth 2003, Lele and Kurien 2011).

\section{STUDY REGION AND METHODS}

Our study region, Jambi Province, lies in the eastern lowlands of Sumatra, Indonesia. In Jambi Province, $7942 \mathrm{~km}^{2}$ of forest were cleared between 1990 and 2013, which corresponds to $35.2 \%$ of the 1990 forest area (Melati 2017). Most land use changes have taken place in the lowlands of Jambi Province, which today are dominated by monoculture rubber (Hevea brasiliensis) and oil palm (Elaeis guineensis Jacq.) plantations. Monoculture rubber plantations have been developed in Jambi Province since the Dutch colonial times (Feintrenie and Levang 2009); oil palm cultivation started in the mid-1980s and has expanded to almost $9000 \mathrm{~km}^{2}(18 \%$ of the province's territory) in 2017 (BPS Indonesia 2018). 
Fig. 1. Study region of the Tembesi watershed in Jambi Province, Sumatra, Indonesia.

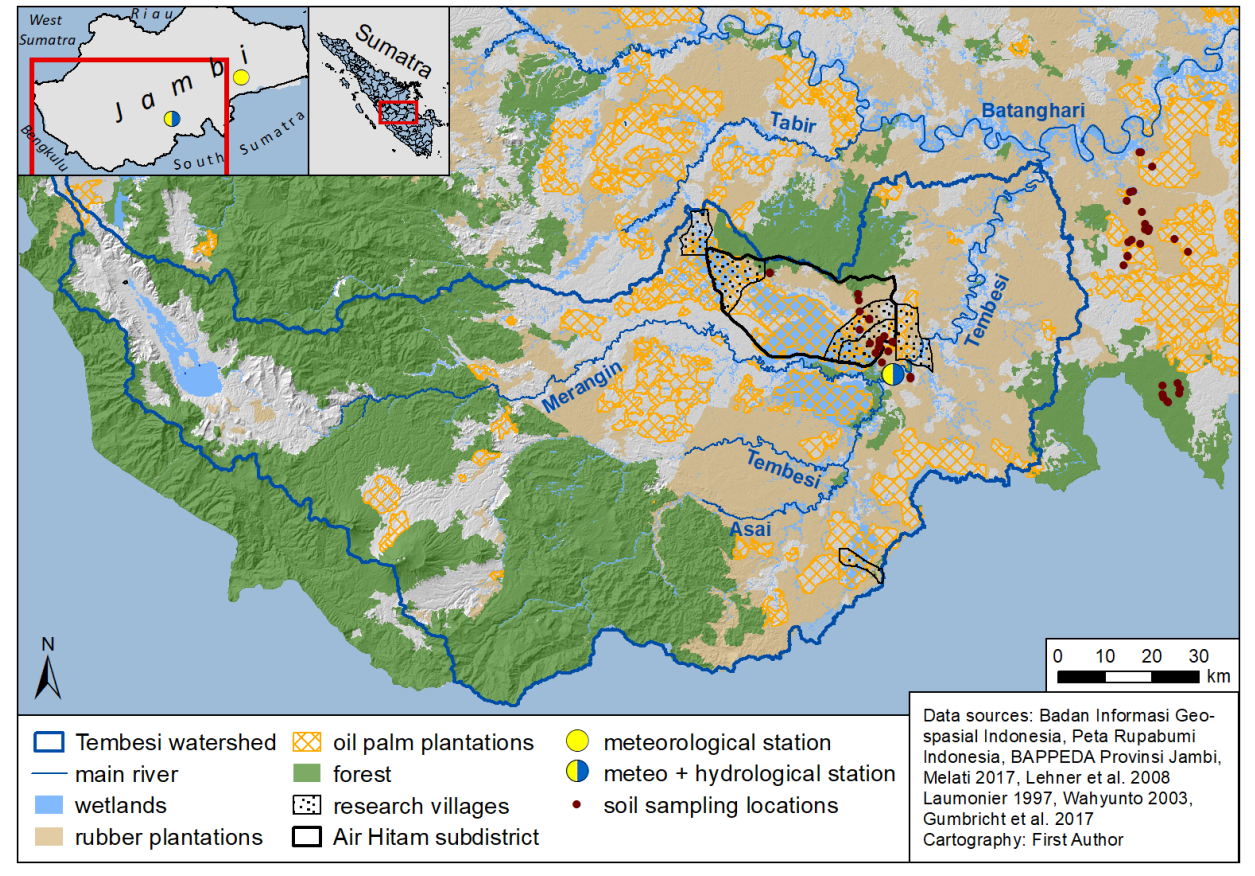

The lowland rivers of Jambi Province show strong seasonal fluctuations between the dry and the wet season. Consequently, large areas in the province's lowlands are inundated during the rainy season. In the Batanghari watershed $\left(44,595 \mathrm{~km}^{2}\right)$, the largest watershed in Jambi Province, $2282 \mathrm{~km}^{2}$ of land across 222 villages is affected by regular flood events (Minister of Public Works 2012).

Our paper presents findings with a focus on the lowlands of the Tembesi watershed, the largest subwatershed of the Batanghari $\left(12,819 \mathrm{~km}^{2}\right)$. This focus was chosen because of the dynamic land use change in this area, the number of people affected by flooding, as well as data availability. The watershed's lowlands cover large wetland areas, which include peatland areas of around $440 \mathrm{~km}^{2}$ (see Fig. 1; Wahyunto and Subagjo 2003, Biagioni et al. 2015). Today, land use in the lowland areas of the Tembesi is dominated by agriculture, mainly oil palm and rubber plantations that account for $52 \%$ of the watershed's area (see Fig. 1; Melati 2017). The climate in the watershed's lowlands is tropical humid (annual average air temperature of $26.5^{\circ} \mathrm{C}$, annual precipitation of 2235 $\mathrm{mm}$ year $^{-1}$ ) with a wet season from October to May (Sulthan Thaha meteorological station, as cited in Drescher et al. 2016). According to data published in local newspapers, the typical seasonal fluctuations of the Tembesi water levels in the watershed's lowlands vary between 5 and $11 \mathrm{~m}$ (Anton 2017, Saputra 2017). All data analyzed for this study was obtained within the EFForTS collaborative research center (https://www. uni-goettingen.de/en/310995.html)

\section{Qualitative interview data}

Our analysis builds on two different sets of qualitative interview data obtained from semistructured and informal interviews (total number of interviews $=91$; Bernard 2011). All interviews were conducted during long-term (2-6 months) field stays in Jambi Province between 2012 and 2017. Interviews were conducted in English and Indonesian with the help of local assistants. Detailed notes and memos were written down during or shortly after the interviews. In addition, audio-recorded interviews were transcribed in Indonesian. All interview notes as well as excerpts from transcripts were coded for content (Mayring 2000) using MAXQDA (V. 11) software.

Local ecological knowledge on changing flooding regimes Interviews of the first dataset were mainly conducted in the subdistrict Air Hitam (Fig. 1). In this subdistrict, three villages were chosen along an upstream-downstream continuum of the eponymous Air Hitam River. In this subdistrict, interview partners from 33 different households were interviewed. Interview partners were chosen according to snowball and purposive sampling methods (Flick 2016). Purposively selected interview partners included village government representatives, heads of farmer groups, village elders, and villagers who were directly affected by flood events, either on their housing plot or on their plantations. In addition to the households in the Air Hitam subdistrict, eight households, who own plantations in riparian areas that were also sampled for soil property analyses within the frame of this study, were purposively selected for interviews. Several of the interview partners were interviewed repeatedly during consecutive field visits, combining both formal and informal interview situations, and often involving family members or friends present during the interview situation (total number of interview situations $\mathrm{n}=69$ ). The interviews focused on interrogating people's observations of changes in local flooding regimes, their individual evaluations of possible causal relations and the implications for the individual households. 


\section{Local knowledge on land use history and management of} wetlands

Because of the interview partners' specific concern about land use change in wetland areas, an analysis of the second dataset aimed to explore the specific land use characteristics of wetland areas in the Tembesi watershed. Therefore, we compared land use history and management of wetland areas across six villages, the territories of which include vast wetland areas. In addition to the three villages in the Air Hitam subdistrict, our case study comparison comprised three further villages within the lowlands of the Tembesi watershed. Interviews conducted in these villages included data from former investigations within the EFForTS research project (Kunz 2016, Rödel 2018) that were made available for this study (additional number of interviews $n=22$ ). We define wetland areas as areas where water covers the soil or is near the surface of the soil either permanently or temporarily (Ramsar Convention Secretariat 2016). This includes riparian floodplains, swamps, as well as peatlands.

The presence of a foreign researcher most certainly influences the way interview partners recount a certain topic, e.g., by providing an answer they expect will please the researcher (Berger 2015). We aimed to reduce such response biases through conducting long-term qualitative research with repeated visits to the studied villages. Qualitative interview techniques were chosen as a method because they allow for bottom-up and in-depth analyses of people's evaluation of local environmental change. Contrary to predefined questionnaires, the use of open-ended questions and a more natural and spontaneous course of conversation allows researchers to create trusting and less formal interview situations. These are helpful for avoiding response biases because they allow the researcher to encourage interview partners to recount environmental changes on their own initiative. They further provide room for more detailed descriptions of environmental changes and reveal insights into the importance of flooding for people's daily life. Information obtained during interviews was then cross-checked in subsequent interviews with interview partners from different social groups. Finally, interview data was triangulated with participative observation, including several visits to villagers' plantations and different river sections.

\section{Quantitative scientific measurements}

River water level

The water level of the Tembesi River was measured at Pauh hydrological station $\left(02^{\circ} 08^{\prime} 55^{\prime \prime} \mathrm{S}, 102^{\circ} 48^{\prime} 22^{\prime \prime} \mathrm{E}\right)$, which is located at the mouth of the Air Hitam River to the Tembesi River (Fig. 1). The data for this analysis was provided by the Public Works Agency for Water Resources (Dinas Pekerjaan Umum Bidang Sumberdaya Air) and covers the period 1997-2016. The river catchment area at Pauh hydrological station covers an area of $10,760 \mathrm{~km}^{2}$ ( $84 \%$ of the Tembesi watershed). Water levels were recorded once per day between 8 and 9 am, local time, with an automatic water level recorder that uses a floating ball as a mechanical trigger (Roni 2005). River discharge was derived from a site-specific rating curve.

Based on villagers' observations of changing flooding regimes and building on the approach of Wang et al. (2006) and Zhang et al. (2009), we analyzed a potential increase in flood frequency and intensity as well as potential shifts in seasonal patterns of flood events. To this purpose we investigated (a) the number of days with extreme water levels of the Tembesi River, (b) the average water level rise as well as the frequency and intensity of flash floods, and (c) the average seasonal water level and possible changes. For (a) we defined extreme water levels as water levels when the Tembesi River overflows its natural dams $(11 \mathrm{~m})$. This threshold is based on the reported typical water level of 5-11 m (Anton 2017, Saputra 2017) and double checked with river water level data for days when flood events were reported in the local online newspaper or by the National Board for Disaster Management (BNPB 2019). For (b) we compared the change in water levels between two subsequent days over the period 19972016 and defined a flash flood as an event with water level rise $>$ $1 \mathrm{~m}$ over two consecutive days. For (c) we calculated the mean water level for each month.

\section{Precipitation}

The only lowland meteorological stations in the vicinity of our study region that offer long-term meteorological measurements are at Jambi Sultan Thaha Airport $\left(01^{\circ} 38^{\prime} 17^{\prime \prime} \mathrm{S}, 103^{\circ} 38^{\prime} 40^{\prime \prime} \mathrm{E}, 25\right.$ $\mathrm{m}$ a.s.1.), which has been taking measurements since 1978, and in the village Pauh $\left(02^{\circ} 11^{\prime} 09.6^{\prime \prime} \mathrm{S}, 102^{\circ} 49^{\prime} 01.1^{\prime \prime} \mathrm{E}, 43 \mathrm{~m}\right.$ a.s.1.), where measurements have been available since 2007 (Fig. 1). Both meteorological stations are owned and run by the Indonesian Meteorological Service (BMKG). The areal distance between the two meteorological stations is approximately $110 \mathrm{~km}$ and the areal distance between the Pauh meteorological and hydrological stations is approximately $4 \mathrm{~km}$. Both meteorological stations are located inland, within similar land use structures and relatively flat terrain. Precipitation pattern in the lowlands are mostly dominated by very local and temporary convective rain showers. Precipitation patterns and intensities may thus differ substantially even within small distances. We analyzed monthly accumulated precipitation, precipitation intensity, and seasonal distribution. Precipitation intensity for both meteorological stations was calculated following the SDII climate index (Zhang et al. 2011), where the total sum of precipitation during consecutive wet days (precipitation $>0.1 \mathrm{~mm} \mathrm{~d}^{-1}$ ) is divided by the total number of consecutive wet days.

\section{Land use change}

Our land use change analysis builds on a comparison of existing land use maps for Jambi Province from 1990 and 2013 (Melati 2017). For the purpose of this study, the land use classes were reclassified to fit our research questions and land use maps were reanalyzed for the section of the Tembesi watershed.

The maps elaborated by Melati (2017) were based on mixed land use/land cover maps originally developed by the Indonesian Ministry of Environment and Forestry (MoEF; Margono et al. 2016). The classification of these land use/land cover maps was based upon a visual interpretation of $30 \mathrm{~m}$ spatial resolution Landsat imagery with a minimum mapping unit of 6.25 ha. The original 23 classes defined by Margono et al. (2016) were enhanced further in a subsequent visual interpretation by Melati (2017) who regrouped some of the former land use/land cover classes to fit land use in Jambi Province. During this enhancement, formerly categorized estate crops were further differentiated into rubber and oil palm land use systems. For this study, we grouped the resulting land use classes by Melati (2017) into the seven most relevant land use classes, namely forest, mixed agriculture, bush/ bare land, rubber plantations, oil palm plantations, settlement, and water. 
Table 1. Quotes illustrating villagers' perceptions of changing flooding regimes. ${ }^{\dagger}$

Perceptions of changing flooding regimes

Q1: "[The flooding in the past] was different, very different. In the past when it only rained for one day, the river did rubber farmer (riparian plantation, 14 not directly overflow. But now, after one hour of heavy rain, it already overflows. ... It started to be like that ever since Nov. 2017) many people opened the land for

oil palm. ... Now, there is constant flooding."

Q2: "Flooding happened since the past. But as far as I remember, in the past flooding occurred rarely, and it was rarely very high. Sometimes, once in five years there was a big flooding, but now it happens almost every year."

Q3: "Now it is difficult to predict [the flooding]. Normally, ... starting from October, November, December, there would be flooding. But last year, in May, and in April, there was flooding as well. We cannot predict it anymore. In the past, when the forest was still wide, we could still predict the flooding."

${ }^{\dagger}$ Translations by J. Merten. village government representative (Air Hitam, 13 July 2016)

village government representative (Air Hitam, 7 June 2016)
To map wetland areas, we combined available wetland maps for Jambi Province, elaborated by Gumbricht et al. (2017; https:// www2.cifor.org/global-wetlands/), Wahyunto and Subagjo (2003), and Laumonier (1997). An additional land use change analysis was performed on these areas using the land use data provided by Melati (2017).

\section{Soil bulk density and water infiltration capacity}

Published bulk density data $\left(\mathrm{g} \mathrm{cm}^{-3}\right)$ from well-drained sites (Allen et al. 2016) as well as unpublished data from riparian sites were used to evaluate soil compaction after the conversion of forests to monocultures. Bulk density samples were weighed and dried at $105^{\circ} \mathrm{C}$ until constant weight. The data consisted of five replicates per site and soil depth. Sampling depth intervals were $0-10 \mathrm{~cm}$, $10-30 \mathrm{~cm}$, and $30-50 \mathrm{~cm}$ soil depth. Sampling sites represented six sites from reference forests, six from rubber, and six from oil palm plantations on well-drained mineral soils as well as four sites of each land use system on riparian soils. Three well-drained mineral soil sampling sites were located within the Tembesi watershed whereas three well-drained mineral sampling sites, as well as the riparian soil sampling sites, were located just outside the watershed, but within the same lowland of Jambi province (Fig. 1). Acrisols with a clayish to sandy loam texture were the dominant soil type in well-drained mineral soils (Guillaume et al. 2015), whereas riparian soils were classified as stagnic Acrisol and Stagnosols with a loamy texture (Waite et al. 2019).

To assess the water infiltration capacity of soils, we measured saturated soil hydraulic conductivity $\left(\mathrm{K}_{\mathrm{f}}, \mathrm{cm} \mathrm{h}^{-1}\right)$, which describes the movement of water through soil under water-saturated conditions. The main measurements were performed with a dualhead infiltrometer (Saturo, Meter, USA) in a commercial oil palm plantation where a biodiversity enrichment experiment was established in 2013 (EFForTS-BEE; Teuscher et al. 2016). In this experiment, multiple native tree species were planted and natural regeneration of the vegetation was allowed. The experimental plots have varying tree diversity levels (from 0 to 6 native tree species) and plot sizes (from $25 \mathrm{~m}^{2}$ to $1600 \mathrm{~m}^{2}$ ) following a random partition design (Teuscher et al. 2016). We carried out one measurement per plot in March 2018 in the subplot in four control plots (management-as-usual oil palm monoculture plantation) and 33 experimental plots where different tree species have been planted and vegetation regenerates naturally (see Table A1.1). We carried out additional, confirmatory measurements of $\mathrm{K}_{\mathrm{fs}}$ with a conventional manual double-ring infiltrometer in a commercial, intensively managed monoculture oil palm plantation in the same region (PTPN VI, at approx. $40 \mathrm{~km}$ distance from the biodiversity enrichment experiment). Six study plots were measured between June and September 2018.

\section{Groundwater level}

To investigate the effect of the land use system on groundwater level, we measured groundwater levels in oil palm and rubber riparian monocultures as well as in forest riparian locations with an OTT Orpheus Mini water level logger (OTT HydroMet GmbH, Kempten, Germany). Measurements were conducted at the same 12 riparian locations that were also sampled for soil bulk density. The logger was installed at a depth of between 2.5 and $4.5 \mathrm{~m}$ in a metal borehole equipped with a fine sieve on its lower end. Data was available from July 2017 to March 2019 at four different locations for each of the three land use systems (forest, rubber plantation, oil palm plantation).

\section{Statistics and data analyses}

We applied the Mann Kendall Trend Test (M-K test; Gilbert 1987) to investigate possible changes in the seasonal and monthly pattern of river water level and accumulated precipitation. The M-K test $\tau$ ranges from -1 to 1 where values above 0 indicate a positive trend whereas values below 0 indicate a negative trend and trends are significant for $p<0.05$. To test for statistical differences in soil bulk density and $\mathrm{K}_{\mathrm{fs}}$ between different land use systems, we performed a nonparametric Kruskal-Wallis Test (differences are significant for $p<0.05$; Townend 2004). All statistical analyses and graphing were performed using R-studio (version 1.1.463), except for the land use change analyses, which were performed in ArcMap (version 10.6.1) and Excel and visualized with the help of the online tool sankeyMATIC (http://sankeymatic.com/).

\section{RESULTS}

\section{Qualitative interview data}

\section{Local ecological knowledge on changing flooding regimes}

Of 33 interview partners in the Air Hitam subdistrict, 29 mentioned having perceived changes in the intensity, frequency, or predictability of flooding over the last $10-15$ years. A common observation among villagers was that flooding nowadays would occur faster, and even after short rainfall events. In their memory, flooding in the past had only occurred after prolonged rainfall (Table 1: Q1). Heavy flood events, in the past common at a return period of about five years, nowadays were said to occur almost 
Table 2. Quotes illustrating villagers' evaluations of possible causes of changing flooding regimes. ${ }^{\dagger}$

Possible causes of changing flooding regimes

\section{Deforestation}

Q4: "In the past the water did not flow down that strong, because it was held back by the trees. But now, as soon as it rains there will be flooding. All the water accumulates in the branches of the river."

Q5: "[The trees] hold back the rain, so that not all the rain falls down. Then we have less flooding. But if all elderly indigenous man (Air Hitam, 16 June the rain falls down, on the earth, the flooding will be higher. ... Because the forest has already been cut, that's 2016) why. The forest can absorb all the disasters."

Soil degradation

Q6:"Maybe it also changed because in our area, the water infiltration is already less. The area where the water can infiltrate is already less, but in the past there was still a lot of forest. So however big the rain was, maybe it was quickly absorbed by the earth, by the soil. But now ... as soon as it rains maybe the water does not enter the earth anymore, it directly flows to the river."

Q7: "The difference is that in the past there was rarely flooding. Because there was no erosion, there were still main other trees. The river was still deep, but now the river is shallow ... because the soil slides off into the river, that's why it is shallow, that is why floods today happen easily."

Ecological function of wetlands

Q8: "Nowadays, we cannot predict the seasons anymore. ... Each time it rains, there is flooding. ... In the past the forest was wide, but now it is all oil palm, that's why the water is absorbed slowly. And also all the peatlands have been destroyed. In the past, when there was still peat, all the water was absorbed by the peat."

Water infrastructure

Q9: "My oil palm in the past never got flooded, but now the water is deep and the oil palms cannot be harvested. Because the water cannot spread anymore. In the past it could flow over there [direction of peatlands], but now it is blocked by the company's dam, and then the water flows over here. In the past the water flowed to [village name]. The water split [into several arms], but now, because there is the dam, the water flows to the village."

Q10: "In the past, before there was a dam built around inti [the company's plantation], the flooding would drop fast. Now because of the dam, it takes longer for the water level to drop. The water comes fast, but drops slowly. ... [Before the dam was built] the flooding lasted two days, and then it would drop for two days. After five days the water was already gone. ... But now, it lasts at least half a month, if it is a big flooding."

Climate change

Q10: "The seasons are not certain anymore today ... Normally, the flooding seasons starts in November ... [It] lasts 4 months. But because there is a change in the weather, we cannot predict it anymore. ... The amount 2017) of rain nowadays is not certain anymore. ... In the past it was comfortable. ... Our ancestors, when they wanted to plant rice, they would count the day, would count the month. ... But now it is difficult because of the change, the change in the weather."

${ }^{\dagger}$ Translations by J. Merten. rubber farmer (riparian plantation, 14 Nov. 2017)

rubber farmer (riparian plantation, 15 Nov. 2017)

village government representative (Air Hitam, 15 Aug. 2016)

oil palm farmer (Air Hitam, 21 July 2016)

oil palm farmer (Air Hitam, 22 June 2016)

rubber farmer (riparian plantation, 14 Nov. rubber every year (Table 1: Q2). Moreover, villagers complained that contrary to former seasonal patterns of flooding, today, the timing of flood events was no longer predictable (Table 1: Q3). Only five farmers residing in wetland areas had noticed decreases in flood height and length, which in most cases can be explained by drainage activities on these lands.

Explanations given for these observed changes in flooding regimes were multiple. In total, 25 of the interview partners associated changes in intensity and frequency of flood events directly with land use change and plantation management. They agreed that flooding regimes started to change after vast forest areas had been converted to rubber and oil palm plantations. Because of this conversion, according to them, the capacity of the landscape to "retain" or "save" water had decreased. Among the villagers, forests were known to "hold back" rainwater and release it only slowly to the rivers (Table 2: Q4). Individual interview partners referred to forests as acting as a "protective shield" that would prevent the occurrence of natural disasters (Table 2: Q5).

The capacity to store water in the landscape was attributed to forest areas, but not to plantations. Some farmers had observed that rainfall in their plantations could not be absorbed and retained by the soil (Table 2: Q6). Others further observed that rainfall in their plantations had flushed away large quantities of soil. This soil was then observed to flow into the rivers where it would result in shallower riverbeds (Table 2: Q7). In addition to the protective function of upstream forest areas against flood occurrence, individual interview partners also highlighted this function in regard to swamp and peat areas. As a village head recounted, before these peatlands were converted to oil palm plantations, they had absorbed and stored large amounts of water (Table 2: Q8).

Perceived causes for changes in the temporal predictability of flood events were not as consistent as for changes in flood frequency and intensity. Some interview partners associated seasonal changes in flood events with land use change (Table 1: Q3, Table 2: Q8). Others, however, also perceived that rainfall would no longer follow seasonal patterns and had become difficult to predict (Table 2: Q10).

Villagers owning land close to rivers had further noted a very recent (3-5 years) change in flooding regimes. This change was attributed to the construction of flood control infrastructure by 
oil palm companies managing wetland areas. Newly constructed dams and drainage gates were reported to lead to a redistribution of floodwaters. These were blamed for increasing the length and depth of flood events on smallholder farmers' plantations located adjacent to or downstream of such infrastructure and further complicating villager's prediction of flood events (Table 2: Q9 and Q10).

The reported increases in flood frequency and intensity have significant socioeconomic impacts for villagers in our case study villages. Increases in flood frequency, as well as difficulties in predicting seasonal flood events, are of particular importance to food crop farmers, who often cultivate riparian floodplains (see introductory quote of this article). For such crops, unexpected flood events, according to our interview partners, often imply complete harvest failures. According to interview partners, but also documented in government reports and local media, such harvest failures caused by flooding constitute a major reason for food crop farmers to convert their fields into oil palm plantations (Bakhori 2010, The Jakarta Post 2014, Jambi Provincial Government 2016). For the interviewed rubber and oil palm farmers, increases in flood frequency and intensity often imply a reduction of tree and palm productivity as well as an impairment of harvesting activities, fertilization, and the transport of plantation produce. Moreover, villagers residing in settlements adjacent to rivers reported being evacuated from their houses several times during the past years.

\section{Land use history and management in wetland areas}

To analyze land use history and management in wetlands areas in the Tembesi watershed we compared interview data across six case study villages with vast wetland areas. Interviews revealed that wetland areas in our case study villages were only extensively used before the mid-1980s. In autochthonous villages, riparian floodplains were traditionally cultivated only during the dry season and mainly planted with staple crops such as dry rice, corn, or soybean. Shallow swamp areas were partly used for wet-rice cultivation. Deeper swamp and peatland areas, on the contrary, mainly remained forested.

Starting in the mid-1980s, forested wetlands in our case study villages were progressively converted into plantation systems. At that time a national resettlement program (transmigrasi) aimed, inter alia, at the economic development of supposedly undeveloped areas across Jambi Province, including expansive peatland areas (for more details see Fearnside 1997). Three of our case study villages were established under this program. Following the establishment of these villages, peat swamp forests adjacent to them were converted into industrial oil palm and rubber plantations. These plantations were jointly managed by settlers and industrial companies. In the other three autochthonous villages, plantations expanded into wetland areas more recently, starting around the early 2000s. A profitable plantation development on these soils requires substantial financial and technical capital for water management. Therefore, villagers interviewed argued that the conversion of wetland forests was mainly initiated by independent private and commercial investments that progressively expanded into areas that were formerly considered marginal. Smallholder farmers who independently tried to develop these areas often sold their land or left it only sporadically managed.
Nowadays, wetland areas in all studied villages are almost exclusively planted with monoculture oil palm plantations. According to the interview partners, the oil palm is the only crop known that can be profitably managed in inland wetlands. A rubber plantation developed on peat soils in one of the transmigration villages had been abandoned after a few years because of extremely low productivity. Annual crops planted in wetland areas have decreased in extent over the past decades because of economic disincentives as well as the above-mentioned challenges associated with changing flooding regimes.

Changes in local flooding regimes appear to also concern companies and private investors who own oil palm plantations in the wetlands of our case study villages. Prior to plantation development, these had typically established large-scale drainage systems on their lands. In several cases, however, these drainage systems have recently been complemented with flood protection infrastructure such as flood control dams. Along the Air Hitam River, at least three larger oil palm companies have built new flood control dams during or shortly before our field visits (2012-2017; Fig. 2). According to a representative of one of these companies, the need for additional water infrastructure arose because of an observed increase in flood frequency. In accordance with the villagers' observations, he associated this increase with upstream deforestation activities. Consequently, the company constructed additional drainage channels and flood control dams, and made use of water pumps to mitigate flood impacts on their plantations. According to the villagers, such infrastructure redistributes floodwaters locally, increasing the frequency and intensity of flood events on their own plantations (see Table 2: Q9 and Q10). In two villages, village authorities complained that they had not been informed about nor involved in the planning of the flood control dams. In consequence, villagers tried to protest against the building of such dams by writing letters to local authorities or organizing roadblocks. Yet, they were not successful in stopping such constructions at the time of research.

Fig. 2. Recently built flood control dam on an agro-industrial oil palm plantation.

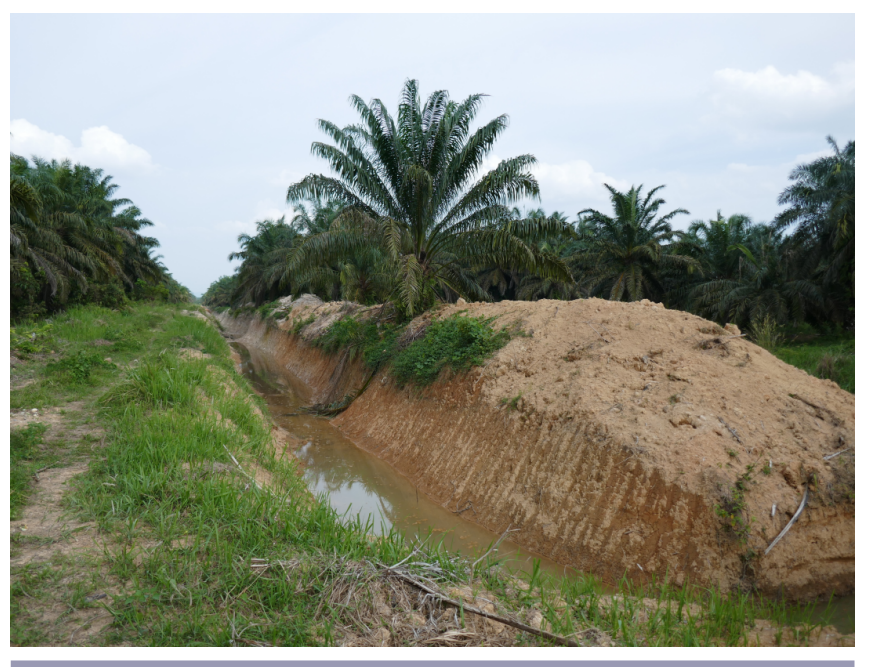


Fig. 3. Accumulated precipitation (a) and mean precipitation intensity index (b) at Pauh meteorological station during the period 2007 to 2016. Days within one year with water level of Tembesi River above 11 $\mathrm{m}$ (c), average change in river water level of the Tembesi River during a flash flood event (d), and fingerprint map of Tembesi River water level at Pauh hydrological station (e) during the period 1997 to 2016 (no data for 2007).
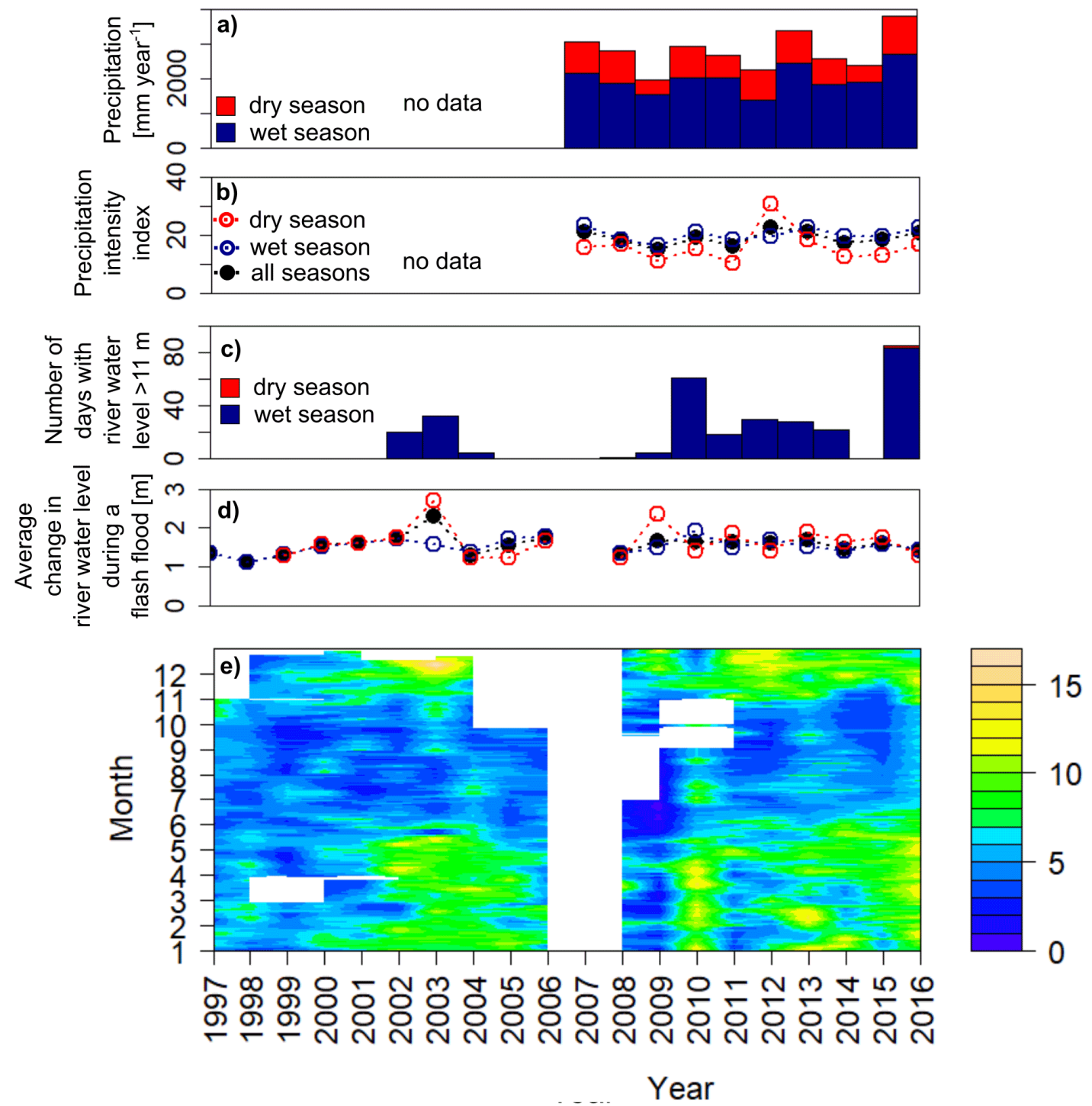

\section{Quantitative environmental measurements}

River water level

To interrogate water level data for the observed changes in the frequency and intensity of flood events we used the nonparametric Mann-Kendall trend analysis and linear regression. On a monthly basis, the Tembesi River at Pauh hydrological station had a mean water level of $6.07 \mathrm{~m}( \pm 1.29 \mathrm{~m}$ standard deviation) over the period 1997-2016 (Table A2.1). On average, mean water levels are $6.88( \pm 1.42 \mathrm{~m})$ in the wet season (October-May), which is $1.9 \mathrm{~m}( \pm 1.35 \mathrm{~m})$ higher compared to the dry season (June-September; Table A2.1). Our trend analysis showed a small but significant increase of annual mean river water levels by $0.10 \mathrm{~m} \mathrm{yr}^{-1}$ over the 20 -year study period (Mann-Kendall $\tau=0.18, p<0.001)$. This observed increase in mean river water levels was more pronounced in the wet season, with $0.12 \mathrm{~m} \mathrm{yr}^{-1}$ (Mann-Kendall $\tau=0.29, p<0.001$ ) compared to the dry season, with a respective increase of $0.06 \mathrm{~m} \mathrm{yr}^{-1}$ (Mann-Kendall $\tau=0.14$, $p<0.05$; Table A2.1). Extreme water levels of $>11 \mathrm{~m}$, as an indicator for flood events, occur almost exclusively during the wet season $(92 \%)$ in coherence with intense precipitation $\left(\mathrm{R}^{2}=0.99\right.$; Fig. 3c, Table A2.2). According to the Mann-Kendall test, the frequency and duration of such extreme river water levels has increased significantly over the study period (Mann-Kendall $\tau=$ $0.45, p<0.01$; Table A2.2).

Because villagers reported that flood events today would occur even after only short rainfall events, we investigated changes in 
Fig. 4. Land use change in the Tembesi watershed and its wetland areas between 1990 and 2013 (based on land use data by Melati 2017). Total area: Tembesi watershed 13,370 km², wetlands $1167 \mathrm{~km}^{2}$.

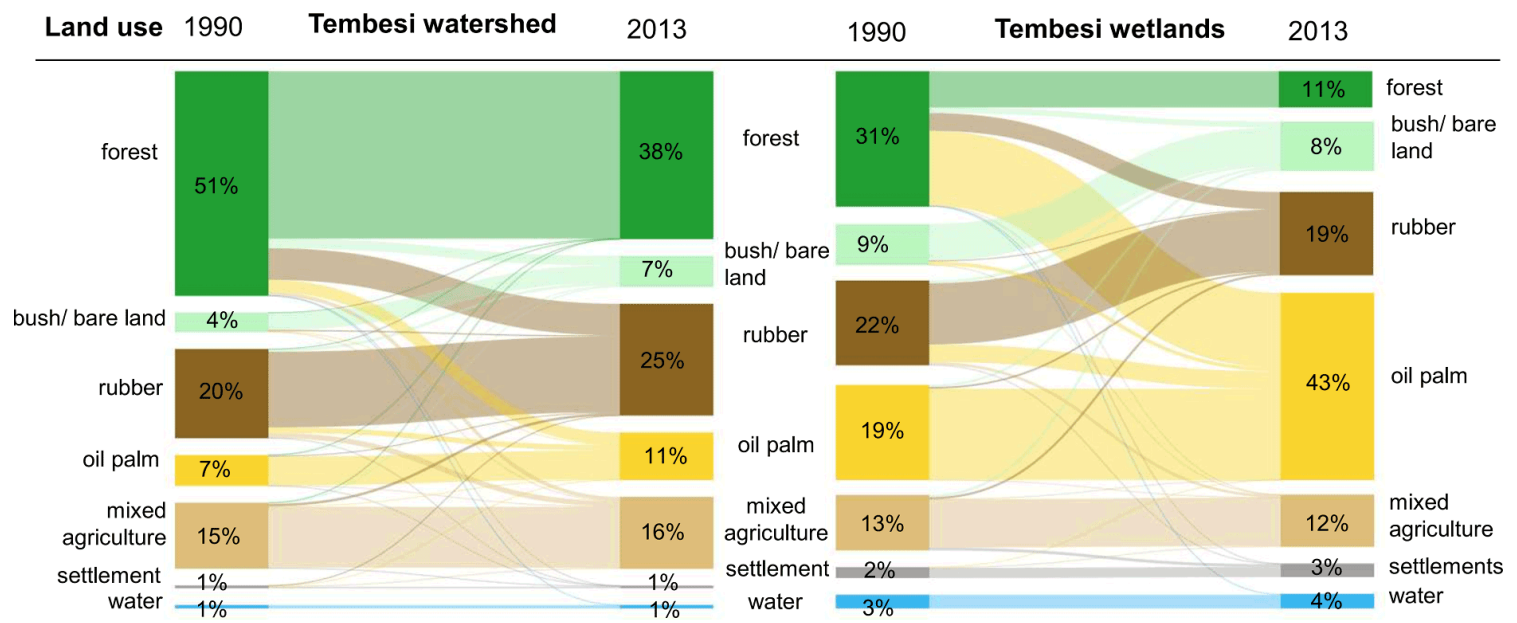

the frequency and intensity of flash floods as well as in the average water level rise. Water levels during a flash flood event (a rapid increase in river water level $>1 \mathrm{~m}$ between two consecutive days) increase on average by $1.59 \mathrm{~m}( \pm 0.67 \mathrm{~m})$ during such events. The frequency and intensity of such flash flood events remained relatively constant over the study period (Mann-Kendall $\tau=0.04$, $p=0.36$ ). However, our analysis of the average water level rise of the Tembesi between two consecutive days (Table A2.3) indicates weak evidence for an increase in the fluctuation of river water levels (Mann-Kendall $\tau=0.16, p<0.01$ ).

To interrogate a changing predictability of flood events we analyzed seasonal patterns of extreme water levels, mean river water levels and flash flood events. However, we did not find any significant shift in the seasonal patterns of mean river water levels (Table A2.1) or flash floods and the increase of extreme water levels was only significant $(p<0.05)$ in the wet season, i.e., in January and November (Fig. 3d, Table A2.2).

The analyses of river water levels show that flooding is an important component of the Tembesi River hydrology. Therefore, we used a digital elevation model and the river network to generate a flood risk map (see Appendix 3). We found that in the case of a 100 -year flood event, about $408 \mathrm{~km}^{2}$ of land adjacent to local rivers would be flooded, with strong negative impacts on local infrastructure, agriculture and villages.

\section{Precipitation}

Precipitation patterns at Pauh meteorological station are well reflected in the behavior of the Tembesi River water levels recorded at Pauh hydrological station. However, precipitation patterns from Jambi airport do not generally explain the water level characteristics at Pauh hydrological station, probably because of the station being located outside of the Tembesi watershed. At both meteorological stations, monthly accumulated precipitation displays large seasonal and annual fluctuations (Fig. 3a, Table A4.1, Table A4.3). At Pauh, November and December show the highest rates of precipitation and the strongest precipitation intensity (Table A4.1 and Table
A4.2), which is also reflected in the annual peak of river water levels during those two months (Fig. 3e). At Jambi, where we have a longer record of precipitation measurements, April shows the highest accumulated precipitation and precipitation intensity is strongest in March (Table A4.3 and Table A4.4).

At both meteorological stations, we found no clear trend in total accumulated precipitation and no shift in the distribution of precipitation between the wet and the dry season (Table A4.1A4.4). At Pauh however, we found a clear trend toward higher precipitation at the end of the wet season in May (Mann-Kendall $\tau=0.60, p<0.05)$ and at the beginning of the wet season in November (Mann-Kendall $\tau=0.56, p<0.05$; Table A4.1), which, for the latter, is in agreement with our findings of increased river water levels at the beginning of the wet season (Table A2.2).

\section{Land use change}

In 1990, about half of the Tembesi watershed was covered with forest areas. Between 1990 and 2013, this forest area decreased by $25 \%$, from $6835 \mathrm{~km}^{2}$ to $5108 \mathrm{~km}^{2}$. Today, most of the remaining forest area is located in the upstream, mountainous area of the watershed (Fig. 1; for an accuracy assessment of the land use classes see Table A5.1). The forest loss in the watershed can mainly be explained by an increase in plantation area as well as in bush/ bare land (Fig. 4). From 1990 to 2013 the area cultivated with oil palm plantations expanded by $54 \%$, from $939 \mathrm{~km}^{2}$ to $1451 \mathrm{~km}^{2}$. Rubber plantations increased by $25 \%$, from $2714 \mathrm{~km}^{2}$ to $3404 \mathrm{~km}^{2}$. The area of bush or bare land increased by $59 \%$, from $597 \mathrm{~km}^{2}$ to $947 \mathrm{~km}^{2}$. In consequence, in 2013, oil palm plantations covered $11 \%$, and rubber plantations $25 \%$ of the Tembesi watershed. The area of mixed agricultural land has remained almost the same over the same period, covering $15 \%$ of the watershed's area in 1990 and $16 \%$ in 2013.

According to the wetland map we created, wetland areas constitute $8.35 \%$ of the Tembesi watershed $\left(1116 \mathrm{~km}^{2}\right)$. In 1990 , about one-third of these wetlands were covered with forests, while $54 \%$ of the wetlands were used for different types of agriculture (Fig. 4). The proportionate loss of forest cover in wetlands was 
even greater than in the whole watershed. From 1990 to 2013, forest areas in the watershed's wetlands decreased by $73 \%$, from $347 \mathrm{~km}^{2}$ to $93 \mathrm{~km}^{2}$. This implies that $15 \%$ of the total forest loss between 1990 and 2013 in the Tembesi watershed occurred in wetland areas although these comprise only $8.35 \%$ of the whole watershed. The converted forest area was almost exclusively planted with oil palm plantations, which almost doubled in area from 1990 to 2013 , from $244 \mathrm{~km}^{2}$ to $479 \mathrm{~km}^{2}$, respectively. In fact, $33 \%$ of all newly developed oil palm plantations in the Tembesi watershed have been established in wetland areas.

\section{Soil bulk density and water infiltration capacity}

Bulk densities of rubber and oil palm plantations in the topsoil $(0-10 \mathrm{~cm})$ were 1.3-fold higher $\left(1.14 \pm 0.05\right.$ and $1.13 \pm 0.05 \mathrm{~g} \mathrm{~cm}^{-}$ ${ }^{3}$, mean \pm standard error) than at the reference rainforest sites (Fig. 5). In contrast to the topsoil, bulk densities in deeper soil layers $(30-50 \mathrm{~cm})$ showed similar values across all land use systems $\left(1.37 \pm 0.03 \mathrm{~g} \mathrm{~cm}^{-3}\right)$.

Fig. 5. Topsoil $(0-10 \mathrm{~cm})$ bulk densities $\left(\mathrm{BD}, \mathrm{g} \mathrm{cm}^{-3}\right)$ at 10 sites each in forest, rubber, and oil palm plantations (sites described in Drescher et al. 2016). The dots represent means and the error bars the according standard errors. Different letters represent significant differences among groups (Kruskal-Wallis test, $p<$ $0.05)$.

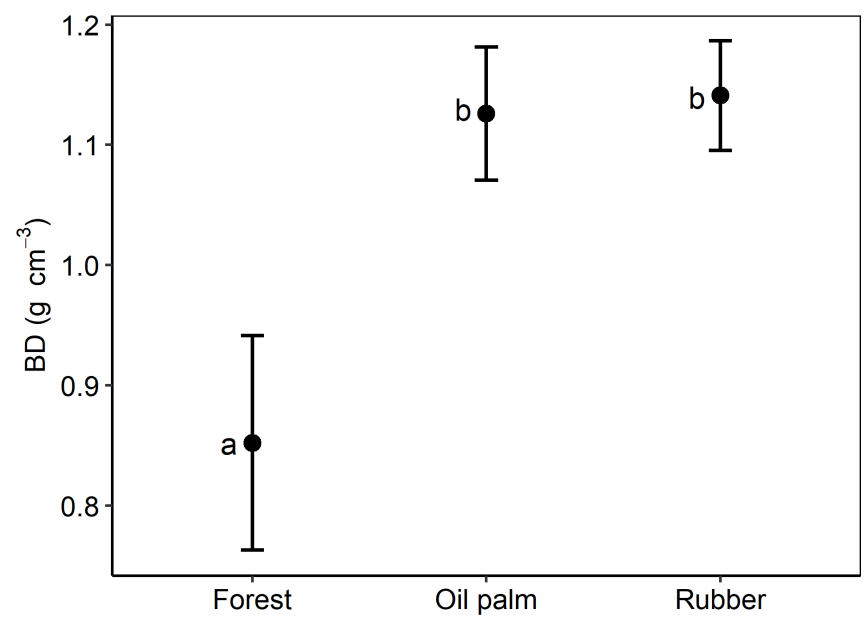

Saturated soil hydraulic conductivity $\left(\mathrm{K}_{\mathrm{fs}}\right)$ in an oil palm monoculture plantation $\left(6.5 \pm 1.7 \mathrm{~cm} \mathrm{~h}^{-1}, \mathrm{n}=4\right)$ was three times lower than in the oil palm biodiversity experiment $(22.6 \pm 2.6 \mathrm{~cm}$ $\mathrm{h}^{-1}, \mathrm{n}=33$; Fig. 6), suggesting higher surface runoff in the former. Additional measurements with a conventional double-ring infiltrometer in another oil palm plantation gave lower $\mathrm{K}_{\mathrm{fs}}(0.7$ $\pm 0.2 \mathrm{~cm} \mathrm{~h}^{-1}, \mathrm{n}=6$ ).

Groundwater levels

Groundwater table (GWT) measurements in riparian areas showed that the mean GWT in the rubber and oil palm plantations is lower than in the forest reference sites (Fig. 7). On average, the GWT during the period July 2017 to April 2019 was $0.55 \mathrm{~m}( \pm 0.27$ $\mathrm{m})$ below the soil surface in the forests, and $1.03 \mathrm{~m}( \pm 0.39 \mathrm{~m})$ and $1.24 \mathrm{~m}( \pm 0.50 \mathrm{~m})$ below the soil surface in the rubber and oil palm plantations, respectively. In addition, GWTs in the plantations (rubber and oil palm) showed higher amplitudes compared to the GWT in the forests (Fig. 7b). After a rainfall event, the GWT in the plantations can increase up to $1.5 \mathrm{~m}$ within a few hours while in the forests, the increase in the GWT after a rainfall event is less pronounced, with a maximum of $\sim 0.5 \mathrm{~m}$ (Fig. 7). Although the mean GWT in the plantations is lower than in the forests, GWTs in the plantations regularly exceed the respective GWT of the forests. This indicates that after a rainfall event, the rubber and oil palm plantations are more prone to flooding than the forests.

Fig. 6. Saturated soil hydraulic conductivity $\left(\mathrm{K}_{\mathrm{fs}}, \mathrm{cm} \mathrm{h}^{-1}\right)$ in oil palm monoculture control plots $(n=4)$ and in plots within the oil palm biodiversity experiment $(n=33$; sites described in Teuscher et al. 2016). The dots represent means and the error bars the according standard errors. Different letters represent significant differences among groups (Kruskal-Wallis test, $p<$ $0.05)$.

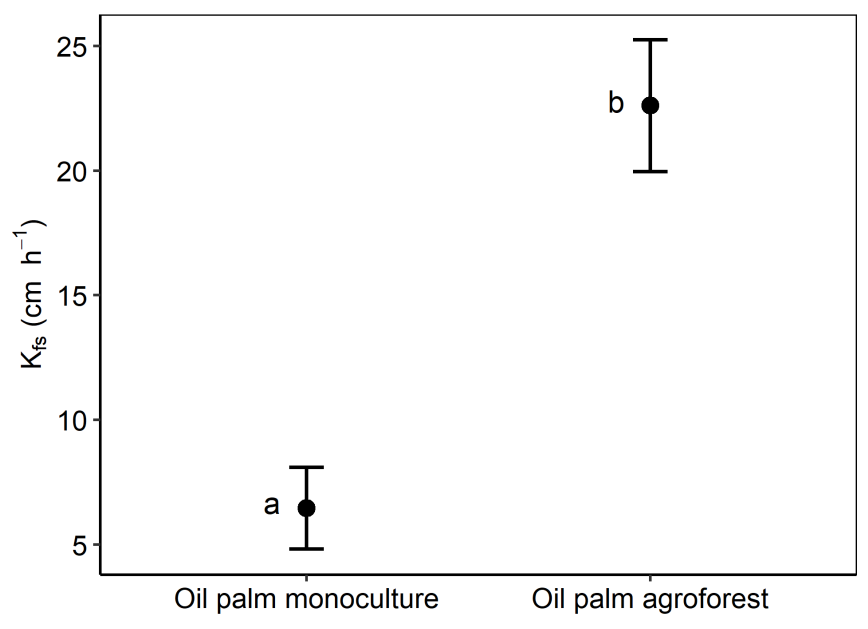

Fig. 7. Development of average groundwater table at forest $(0.55 \pm 0.27 \mathrm{~m}, \mathrm{n}=4)$, rubber $(1.03 \pm 0.39 \mathrm{~m}, \mathrm{n}=4)$, and oil palm $(1.24 \pm 0.50 \mathrm{~m}, \mathrm{n}=4)$ riparian locations during the period July 2017 to April 2019.

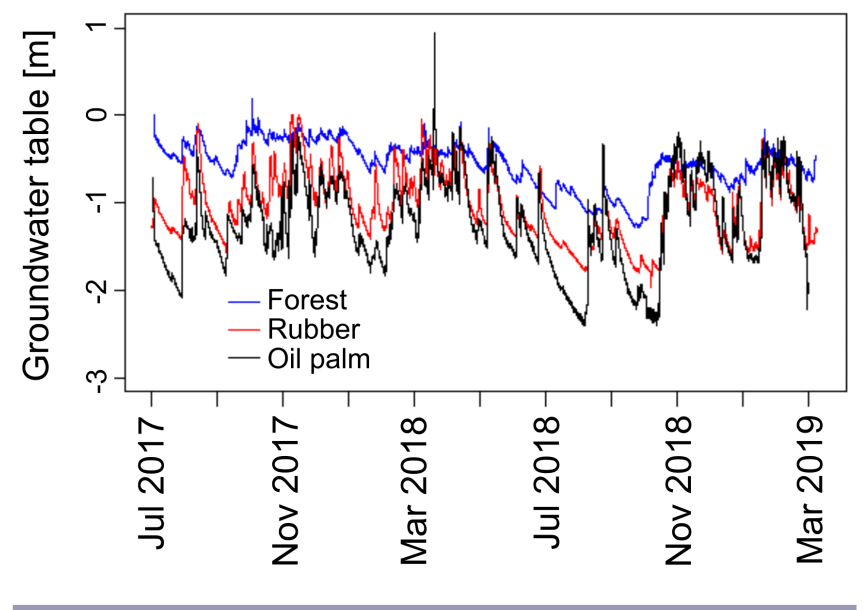




\section{DISCUSSION: INTEGRATING INSIGHTS FROM LOCAL ECOLOGICAL KNOWLEDGE AND SCIENTIFIC MEASUREMENTS}

\section{Comparing villagers' observation of changing flooding regimes with stream flow data}

Villagers interviewed for this study reported an increase in flood frequency and intensity following extensive land use change toward rubber and oil palm monoculture plantations during the past two decades. These findings are in line with the observed increase in frequency and duration of extreme river water levels ( $>11 \mathrm{~m} ; \tau=0.45)$. Government reports from Jambi Province provide some additional support to these measurements as they discuss flooding as an increasing environmental problem across Jambi Province and beyond the Tembesi watershed (Minister of Public Works 2012, Batanghari Watershed Office 2016, Jambi Provincial Government 2016). They are also in line with other studies across Indonesia, where local people associated increases in flood frequency and intensity with land use change from forests to oil palm plantations and other types of land use (Obidzinski et al. 2012, Larsen et al. 2014, Wells et al. 2016, Kelley and Prabowo 2019). Our findings further correspond with studies showing increases in streamflow (Adnan and Atkinson 2011) and in the number of days flooded (Tan-Soo et al. 2016), which is associated with land use conversion to rubber and oil palm plantations.

The interviewed villagers further reported that following land use conversion, flood events have become difficult to predict because water levels today rise faster after rainfall events and the occurrence of flooding has partly shifted in seasonality. A decreasing predictability of flood events following land conversion has also been a common observation by villagers in different areas across Indonesia (Leimona et al. 2015, Kelley and Prabowo 2019). Our water level data, however, showed no substantial evidence supporting these observations by local villagers. Flash flood events of the Tembesi River have not changed in frequency, intensity, or seasonality over time and significant increases in extreme water levels were only found during the wet season. Only the slight increase in average water level rise $(\tau=0.16)$ provides a small indication supporting villagers' observation of larger fluctuations in water levels. Because discharge data is only available from one hydrological station in the Tembesi watershed, our data, therefore, provide very selective insights into hydrological processes at the watershed scale. As the catchment area upstream of our hydrological station covers over $10,000 \mathrm{~km}^{2}$, flash flood events in smaller subcatchments may not result in significantly higher water levels of the Tembesi River. In general, it has been found that the impacts of land use change on river water levels may be larger in smaller watersheds (Bruijnzeel 1990, van Dijk et al. 2009). Farmers who own plantations adjacent to smaller streams, e.g., the Air Hitam River, may thus observe larger changes in water levels than are reflected in the water levels of the Tembesi River. Indications supporting this hypothesis can be found in our measurements of groundwater tables, which show rapidly increasing water levels in rubber and oil palm plantations after rainfall events.

\section{Potential contributions of local climate change to changing flooding regimes}

Several interview partners reported seasonal shifts in local rainfall patterns, which could thus potentially provide an explanation for the villagers' reports that flood events have become difficult to predict. Our analysis of precipitation data may partly explain the villagers' complaints as it indicates a clear shift in the seasonal distribution of precipitation toward higher precipitation rates at the end of the wet season in May. Similar accounts about increasingly unpredictable rainfall patterns were reported from farmers across different regions in Jambi Province (Merten et al. 2016, Martens 2017, Rödel 2018). Considering this widespread observation, the measured changes in the seasonal distribution of precipitation appear relatively small. Further data from different meteorological stations across Jambi Province would thus be needed to discuss the villagers' observation of changing seasonal rainfall patterns in more detail.

Changes in rainfall patterns could further provide an explanation for the measured increase in the average water levels of the Tembesi River. However, our analysis of precipitation data at Pauh and Jambi airport meteorological station showed that the total amount of precipitation as well as the overall precipitation intensity has remained relatively constant over the past decades. Our precipitation data available for the Tembesi watershed, however, only covers the lowland areas. Hence, we cannot rule out changes in precipitation patterns in the highland regions of the Tembesi River watershed, which may have contributed to the observed increase in water levels.

Deforestation can modify rainfall patterns because of vegetationatmosphere interactions at various spatial scales (Lawrence and Vandecar 2015, Spracklen et al. 2018). Large-scale forest conversion, as in the Tembesi watershed, typically leads to a reduction of rainfall and therefore river discharge (Lawrence and Vandecar 2015). However, this might be different in the case of forest conversion to oil palm plantations in which evapotranspiration remains relatively high (Röll et al. 2019). On the other hand, deforestation in heterogeneous landscapes such as the Tembesi watershed may increase rainfall over deforested areas and thereby increase both river discharge and river water levels (Lawrence and Vandecar 2015). Moreover, global climate change is expected to increase both total annual precipitation and extreme precipitation in Southeast Asia (Ge et al. 2019). Although such trends are not yet identifiable in our precipitation data, such developments could further increase both river discharge and river water levels in the future. Long-term climate records and a dense network of meteorological stations are therefore indispensable for studying the current and future linkages between precipitation and river discharge.

\section{Potential contributions of land use change to changing flooding regimes}

\section{Evidence for altered hydraulic soil properties after forest} conversion

The villagers interviewed in this study reported that flooding regimes started to change after vast forest areas had been converted to rubber and oil palm plantations. Our land use change analysis, together with our measurements of soil properties and groundwater levels in different land use systems, provide indications that the large-scale land use change might have contributed to changes in the ecohydrological functioning of the Tembesi watershed. High soil compaction in monoculture rubber and oil palm land use systems is in line with results of other studies in the tropics, showing that forest conversion and associated soil compaction leads to 1.2 - to 1.3 -fold increases in topsoil bulk 
density (Don et al. 2011, Li et al. 2012). Higher bulk densities in monoculture plantations than in forests are likely the result of severe soil erosion and changes in soil properties (Guillaume et al. 2015, 2016), e.g., compaction caused by heavy machinery during deforestation or subsequent harvesting operations. Such increases in soil compaction may go along with significantly lower saturated hydraulic conductivities $\left(\mathrm{K}_{\mathrm{fs}}\right.$; Pachepsky and Park 2015). Our measurements indicate that subsoil bulk densities (30$50 \mathrm{~cm}$ ) remain unchanged across the different land use systems, which corresponds with a previous study from the region (de Blécourt et al. 2013). However, it has been suggested that increases in topsoil bulk density alone are sufficient to strongly reduce $\mathrm{K}_{\mathrm{fs}}$ in soils of the humid tropics (Hassler et al. 2011). In a metaanalysis, Pachepsky and Park (2015) suggested that topsoil bulk densities of around $1.36 \mathrm{~g} \mathrm{~cm}^{-3}$ form a critical threshold, beyond which they have altered hydraulic properties such as hydraulic conductivity, permeability, and porosity due to soil compaction. In our study, more than $30 \%$ of the assessed oil palm and rubber plantations cross this threshold. Such changes in hydraulic soil properties are further supported by our measurements of saturated hydraulic conductivity $\left(\mathrm{K}_{\mathrm{fs}}\right)$. Our very low $\mathrm{K}_{\mathrm{fs}}$ values coincide with a previous study in the region, where soil water infiltration in oil palm monocultures $\left(3 \mathrm{~cm} \mathrm{~h}^{-1}\right)$ was reported to be $60 \%$ lower than in rubber plantations $\left(7.8 \mathrm{~cm} \mathrm{~h}^{-1}\right)$ and more than 15-times lower than in reference rainforests $\left(47 \mathrm{~cm} \mathrm{~h}^{-1}\right.$; Tarigan et al. 2018). These results, as well as ours, thus point to very low $\mathrm{K}_{\mathrm{fs}}$ in conventionally managed oil palm monocultures, which is most likely related to the described soil compaction. These observations are in agreement with the villager's observation that soils in plantations do not effectively absorb or retain rainwater.

The type of vegetation in riparian areas is critical for infiltration capacity, overland flow, and groundwater recharge (Alvarenga et al. 2017). Our groundwater table (GWT) analysis in riparian areas showed that rubber and oil palm plantations have lower GWTs compared to forests. This might be related to the relatively high soil compaction and the low water infiltration capacities in monoculture plantations, as mentioned above. Higher amplitudes of GWT in oil palm and rubber plantations compared to forests indicate a loss of buffer functions such as flood moderation, groundwater recharge, and soil water storage in the plantations. Hence, our measurements of bulk density, water infiltration, and groundwater tables point to substantial increases in surface runoff after precipitation, which could potentially increase flood frequency and intensity (Bruijnzeel 2004). This line of argument is supported by a previous study in the region, which modeled large increases in surface runoff with an increasing share of rubber and oil palm plantations in a given watershed (Tarigan et al. 2018). Although our water level data from the Tembesi River did not reflect villagers' observation that rainfall nowadays accumulates faster in local rivers than they remember from the past, our measurements of hydraulic soil properties and groundwater levels provide substantial indications that support this observation.

Our analysis of soil water infiltration in oil palm plantations where biodiversity enrichment has been carried out, however, suggests that tree planting and regeneration of natural vegetation could partially restore the very low infiltration capacity. Five years after the establishment of the experiment, average $\mathrm{K}_{\mathrm{fs}}$ in the enriched oil palm plantation was at least three-times higher than in oil palm monocultures. These findings are consistent with a meta-analysis across the tropics that reports on average three-fold increases of water infiltration capacity after afforestation or tree planting in agricultural fields (Ilstedt et al. 2007).

Our measurements thus provide several indications that forest conversion and subsequent alteration of soil properties may explain the measured increase in the Tembesi's water levels. However, especially in larger catchments, the interaction of land use and ecosystem processes increases in its complexity and causes with increasing catchment area (Bruijnzeel 1990, van Dijk et al. 2009). Studies from several river catchments in the tropics have shown that other processes related to land use change and subsequent changes in soil properties, e.g., sedimentation, road construction, missing buffer zones, or illegal gold mining have the potential to further increase river water levels (Allan 2004, Ziegler et al. 2006, Wantzen and Mol 2013, Carlson et al. 2014, Luke et al. 2017). These above-mentioned processes are also found in the Tembesi catchment area and, with the relatively large extent of the river, this myriad of complex land use changes and related interactions may therefore further contribute to the observed increases in river water level.

Increases in the Tembesi river water levels in both the dry and rainy seasons might be explained by the complexity of interacting ecosystem processes. In the case of reduced water infiltration capacity of soils coupled with high (evapo)transpiration rates in oil palm monoculture plantations (Manoli et al. 2018), a reduction of water levels in rivers during the dry season might be expected (Bruijnzeel 1990). Indications for such changes were suggested for oil-palm-dominated landscapes by Merten et al. (2016). Rubber plantations, on the other hand, exhibit lower (evapo)transpiration rates in smallholder-dominated cultivation systems in Jambi (Röll et al. 2019). Therefore, the impact of land conversion on the river water level in larger watersheds with mixed land use systems may be less discernible.

\section{Potential contributions of wetland conversion and water} infrastructure to changing flooding regimes

Despite their important ecological role(Bhowmik 2020), wetlands have often been described and treated as wastelands and hence converted into other land use types (Barbier et al. 1997). Our land use change analysis indicates a much higher rate of forest conversion in wetland areas compared to well-drained sites. According to interview data, this land use change can be explained by both governmentally planned plantation establishment as well as market-driven expansion of oil palm plantation into marginal areas. This trend of oil palm plantations expanding into wetlands areas has also been reported in other regions across Indonesia and Malaysia (Abram et al. 2014, Guillaume et al. 2016, Schoneveld et al. 2019).

Because of plantation expansion into wetland areas, but also because of the reported increases in flood frequency and intensity, flood control infrastructure such as dams and drainage channels have recently been installed across all our case study villages. Although we cannot quantify to what extent such infrastructure has contributed to an alteration of flooding regimes at the landscape level, our interview partners reported that the construction of flood control dams, water pumps, and drainage gates contribute to a redistribution of floodwaters at the local scale. Such developments are considered particularly sensitive 
because government representatives during interviews confirmed that the construction of water infrastructure often happens without legal notice. Accordingly, the first author observed the emergence of social conflicts.

Our interview data as well as observations in the field show that most of the studied wetland areas were managed by or with the support of private companies, external investors, or more welloff farmers. Likewise, Schoneveld et al. (2019) and Kelley and Prabowo (2019) show that plantation development on peat soils and flood prone riverbanks in Indonesia was mainly realized by more well-off farmers, political elites, and private companies that adopted more industrialized land use operations. This concentration of companies and local elites in wetland areas, together with the already mentioned conflicts over water infrastructure, creates a risk of an increasingly unequal distribution of flood damage. Surprisingly, to our knowledge, no study linking oil palm expansion to increasing flood frequency and intensity has yet paid attention to the role of infrastructure in changing flooding regimes or to the associated social impacts.

The large-scale expansion of plantations into wetland areas may also have contributed to changing flooding regimes by reducing the ecohydrological functioning of these ecosystems. Review studies suggest that lowland wetlands may substantially reduce or delay flood events (Bullock and Acreman 2003, Acreman and Holden 2013, Mitsch and Gosselink 2015). Anthropogenic activity in wetlands strongly affects local river systems because of frequent lateral water exchange between rivers and wetlands (Junk et al. 1989, Junk and Wantzen 2004). Although no data on wetland hydrology were available for the Tembesi watershed, the drainage and burning of large areas of peatlands in the watershed (Uryu et al. 2010, NASA FIRMS 2019) is particularly indicative of a degradation of local ecohydrological functions. Drainage and burning of peat soils is known to alter their physical properties, resulting in peat subsidence and compaction, thus reducing the water absorption of peat swamps (Andriesse 1988, Page et al. 2006, Wösten et al. 2008, Evers et al. 2017). Moreover, the subsidence of peat soils is considered to progressively lengthen periods of inundation (Wösten et al. 2006, Hooijer et al. 2015, Sumarga et al. 2016).

\section{CONCLUSION AND FINAL REFLECTIONS}

Our analysis showed that the observed and measured increase in flood frequency and intensity within the Tembesi River catchment area is most likely driven by land use change from forests to monoculture plantations. This development appears to be related to soil compaction, decreasing water infiltration rates, and, therefore, higher surface runoff. It might further be aggravated by the expansion of oil palm plantations into wetland areas and the subsequent construction of drainage and flood control infrastructure.

Our study illustrates how interrogating local ecological knowledge and integrating it with multidisciplinary scientific measurements can drive forward problem-centered research on the linkage between land use change and flooding. This study benefited from data integration in three important ways. First, local people's reports of changes in flooding regimes following land conversion, draw our attention to a problem of environmental change previously not accounted for by our research project. We thus build upon local people's ecological knowledge to then interrogate datasets from different disciplines, whether they provide indications confirming villagers' observations and evaluations or not. None of the data analyzed were initially collected for the purposes of studying flooding, and hydrological data provided by the provincial government in Jambi remain scarce and often incomplete. Despite this, the analyzed data provided substantial indications that support people's claims that land use change alters local flooding regimes. The villagers' observations and evaluations matched well with our measurements of extreme river water levels and altered hydraulic soil properties in monoculture plantations. In data-poor regions, such an integration of multidisciplinary datasets may thus help us to gain insights into socially relevant research topics that are otherwise neglected.

Second, villagers' observations of changing flooding regimes, such as increases in the frequency of flood events or more rapidly rising water levels after rainfall, also helped us to define what indicators to look for in local water level data. As a result, our problem-based research approach pointed out significant gaps in our data, which, by analyzing water level data alone, might not have appeared as a gap at all. Although the predictability of flood events appears to be a major concern for local farmers in Jambi, our analyzed data does not mirror seasonal shifts in flood events and only small shifts in seasonal rainfall. Reports of shifting seasonal rainfall patterns, however, have been common across different areas in Jambi Province, and a decreasing predictability of floods has also been reported in other areas with rapid land use change (Leimona et al. 2015, Kelley and Prabowo 2019). This mismatch points to a need for more fine-scaled spatial and temporal monitoring of water levels and precipitation in the area to improve our understanding of the complex linkages between river discharge, land use change, and climate change.

Finally, the integration of local ecological knowledge draws our attention to the multiplicity of processes that influence the occurrence of flooding. Our study reveals that the construction of drainage or flood control infrastructure has aggravated changes in local flooding regimes, thus generating new social conflicts. Newly installed infrastructure was observed to redistribute floodwaters at the local level and thus to play a crucial role in the mediation of the social impacts of flooding. Surprisingly, the role of technical infrastructure in mediating water flows has received little scientific attention in studies connecting land use change with changing flooding regimes. More studies are needed to assess and monitor the hydrological impacts of such water management practices, as well as the social and economic relations that shape these practices.

\section{AUTHOR CONTRIBUTIONS}

JM, CS, MD, HF, LF, DH, NH, AK, EP designed the study. JM, $\mathrm{CS}, \mathrm{NH}, \mathrm{FO}, \mathrm{AH}, \mathrm{JK}, \mathrm{DCZ}$ contributed data to the manuscript. $\mathrm{JM}, \mathrm{CS}, \mathrm{NH}, \mathrm{AR}, \mathrm{EP}$ performed data analysis and interpretation. JM and CS prepared the manuscript. NH, AR, EP contributed to writing the manuscript. JM, CS critically revised the manuscript. All authors discussed the results and commented on the manuscript.

Responses to this article can be read online at: http://www.ecologyandsociety.org/issues/responses. php/11678 


\section{Acknowledgments:}

This publication was funded by the Deutsche Forschungsgemeinschaft (DFG, German Research Foundation), project number 192626868, in the framework of the collaborative German-Indonesian research project CRC 990 (SFB): "EFForTS, Ecological and Socioeconomic Functions of Tropical Lowland Rainforest Transformation Systems (Sumatra, Indonesia)" (http://www.unigoettingen. delcrc990). We thank the EFForTS subproject A05 for contributing additional data to complete the bulk density dataset, as well as Imke Schulze Kalthoff (née Rödel) and Yvonne Kunz for contributing interview data on land use history and management of wetlands areas. We further thank Jasper Knieling for conducting the land use change analysis using ArcMap. We thank Edgar Tunsch, Marek Peksa, Malte Puhan, Frank Tiedemann, and Dietmar Fellert for their technical support. We would also like to acknowledge PT Humusindo, PTPN6, and the smallholder plot owners for allowing us to perform measurements on the plantations as well as all interview partners for sharing their knowledge and perspectives on the research topic. We greatly thank all our Indonesian field assistants who made the extensive field work possible: Agustina Siregar, Yossy Delfitri, Yohana Manurung, Winda Januarista, Basri, Bayu, Darwis, Ardian, and Amrina. Terimakasih banyak! We would also like to thank our Indonesian counterparts for their assistance during field work. Finally, we thank two anonymous reviewers for helping to improve the quality of this article.

\section{Data Availability Statement:}

The data that support the findings of this study are available on request from the corresponding author, J.M.. The data are not publicly available because they contain information that could compromise the privacy of research participants.

\section{LITERATURE CITED}

Abram, N. K., P. Xofis, J. Tzanopoulos, D. C. MacMillan, M. Ancrenaz, R. Chung, L. Peter, R. Ong, I. Lackman, B. Goossens, L. Ambu, and A. T. Knight. 2014. Synergies for improving oil palm production and forest conservation in floodplain landscapes. PLOS ONE 9(6):e95388. https://doi.org/10.1371/ journal.pone.0095388

Acreman, M., and J. Holden. 2013. How wetlands affect floods. Wetlands 33(5):773-786. https://doi.org/10.1007/s13157-013-0473-2

Adam, F., M. Mönks, T. Esch, and M. Datcu. 2018. Cloud removal in high resolution multispectral satellite imagery: comparing three approaches. Proceedings 2(7):353. https://doi. org/10.3390/ecrs-2-05166

Adnan, N. A., and P. M. Atkinson. 2011. Exploring the impact of climate and land-use changes on streamflow trends in a monsoon catchment. International Journal of Climatology 31 (6):815-831. https://doi.org/10.1002/joc.2112

Ahamed, A., and J. D. Bolten. 2017. A MODIS-based automated flood monitoring system for Southeast Asia. International Journal of Applied Earth Observation Geoinformation 61:104-117. https:// doi.org/10.1016/j.jag.2017.05.006
Aikenhead, G. S., and M. Ogawa. 2007. Indigenous knowledge and science revisited. Cultural Studies of Science Education 2 (3):539-620. https://doi.org/10.1007/s11422-007-9067-8

Alila, Y., P. K. Kuraś, M. Schnorbus, and R. Hudson. 2009. Forests and floods: a new paradigm sheds light on age-old controversies. Water Resources Research 45(8). https://doi. org/10.1029/2008WR007207

Allan, J. D. 2004. Landscapes and riverscapes: the influence of land use on stream ecosystems. Annual Review of Ecology, Evolution, and Systematics 35:257-284. https://doi.org/10.1146/ annurev.ecolsys.35.120202.110122

Allen, K., M. D. Corre, S. Kurniawan, S. R. Utami, and E. Veldkamp. 2016. Spatial variability surpasses land-use change effects on soil biochemical properties of converted lowland landscapes in Sumatra, Indonesia. Geoderma 284:42-50. https:// doi.org/10.1016/j.geoderma.2016.08.010

Alvarenga, L. A., C. R. de Mello, A. Colombo, and L. A. Cuartas. 2017. Hydrologic impacts due to the changes in riparian buffer in a headwater watershed. CERNE 23(1):95-102. https://doi. org/10.1590/01047760201723012205

Andriesse, J. P. 1988. Nature and management of tropical peat soils. FAO Soils Bulletin 59.

Anton. 2017. Debit air sungai Batanghari mulai surut. Metro Jambi, 17 March. [online] URL: https://metrojambi.com/ read/2017/03/17/19543/debit-air-sungai-batanghari-mulai-susut

Badan Nasional Penanggulangan Bencana (BNPB). 2019. Data Kejadian Bencana Banjir. BNPB, Jakarta, Indonesia. [online] URL: http://geospasial.bnpb.go.id/pantauanbencana/data/databanjirall. php

Badan Pusat Statistik (BPS) Indonesia (Statistics Indonesia). 2018. Luas tanaman perkebunan menurut provinsi. Badan Pusat Statistik, Jakarta, Indonesia. [online] URL: https://www.bps.go. id/subject/54/perkebunan.html\#subjekViewTab6

Bakhori, S. 2010. Alih Fungsi Sawah Ancam Ketahanan Pangan Jambi. Tempo.co, 23 July. [online] URL: https://nasional.tempo. co/read/265784/alih-fungsi-sawah-ancam-ketahanan-pangan-jambi

Ban, H. J., Y. J. Kwon, H. Shin, H. S. Ryu, and S. Hong. 2017. Flood monitoring using satellite-based RGB composite imagery and refractive index retrieval in visible and near-infrared bands. Remote Sensing 9(4):313. https://doi.org/10.3390/rs9040313

Barbier, E. B., M. Acreman, and D. Knowler. 1997. Economic valuation of wetlands. A guide for policy makers and planners. Ramsar Convention Bureau, Glad, Switzerland.

Batanghari Watershed Office (BWS Sumatera VI). 2016. Laporan akuntabilitas kinerja instansi pemerintah. Balai Wilayah Sungai Sumatera VI, Jambi, Indonesia. [online] URL: http://sda.pu.go. id/bwssumatera6/lakip-2016/

Berger, R. 2015. Now I see it, now I don't: researcher's position and reflexivity in qualitative research. Qualitative Research 15 (2):219-234. https://doi.org/10.1177/1468794112468475

Berkes, F., J. Colding, and C. Folke. 2000. Rediscovery of traditional ecological knowledge as adaptive management. Ecological Applications 10(5):1251-1262. http://dx.doi. org/10.1890/1051-0761(2000)010[1251:roteka]2.0.co;2 
Bernard, H. R. 2011. Research methods in anthropology: qualitative and quantitative approaches. Fourth edition. AltaMira Press, Lanham, Maryland, USA.

Bhowmik, S. 2020. Ecological and economic importance of wetlands and their vulnerability: a review. Page 95-112 in A. K. Rathoure and P. B. Chauhan, editors. Current state and future impacts of climate change on biodiversity. IGI Global. Hershey, Pennsylvania, USA. https://doi.org/10.4018/978-1-7998-1226-5. $\underline{\mathrm{ch} 006}$

Biagioni, S., V. Krashevska, Y. Achnopha, A. Saad, S. Sabiham, and H. Behling. 2015. 8000 years of vegetation dynamics and environmental changes of a unique inland peat ecosystem of the Jambi province in central Sumatra, Indonesia. Palaeogeography, Palaeoclimatology, Palaeoecology 440:813-829. https://doi. org/10.1016/j.palaeo.2015.09.048

Bohensky, E. L., and Y. Maru. 2011. Indigenous knowledge, science, and resilience: what have we learned from a decade of international literature on "integration"? Ecology and Society 16 (4):6. http://dx.doi.org/10.5751/ES-04342-160406

Bradshaw, C. J. A., N. S. Sodhi, K. S.-H. Peh, and B. W. Brook. 2007. Global evidence that deforestation amplifies flood risk and severity in the developing world. Global Change Biology 13 (11):2379-2395. https://doi.org/10.1111/j.1365-2486.2007.01446. $\underline{x}$

Bruijnzeel, L. A. 1990. Hydrology of moist forests and the effects of conversion: a state of knowledge review. Free University, Amsterdam, The Netherlands.

Bruijnzeel, L. A. 2004. Hydrological functions of tropical forests: not seeing the soil for the trees? Agriculture, Ecosystems and Environment 104(1):185-228. https://doi.org/10.1016/j.agee.2004.01.015

Bullock, A., and M. Acreman. 2003. The role of wetlands in the hydrological cycle. Hydrology and Earth System Sciences 7 (3):358-389. https://doi.org/10.5194/hess-7-358-2003

Calder, I. R., and B. Aylward. 2006. Forest and floods: moving to an evidence-based approach to watershed and integrated flood management. Water International 31(1):87-99. https://doi. org/10.1080/02508060608691918

Carlson, K. M., L. M. Curran, A. G. Ponette-González, D. Ratnasari, Ruspita, N. Lisnawati, Y. Purwanto, K. A. Brauman, and P. A. Raymond. 2014. Influence of watershed-climate interactions on stream temperature, sediment yield, and metabolism along a land use intensity gradient in Indonesian Borneo. Journal of Geophysical Research: Biogeosciences 119 (6):1110-1128. https://doi.org/10.1002/2013JG002516

Chong, K. L., K. D. Kanniah, C. Pohl, and K. P. Tan. 2017. A review of remote sensing applications for oil palm studies. GeoSpatial Information Science 20(2):184-200. https://doi. org/10.1080/10095020.2017.1337317

Clough, Y., V. V. Krishna, M. D. Corre, K. Darras, L. H. Denmead, A. Meijide, S. Moser, O. Musshoff, S. Steinebach, E. Veldkamp, K. Allen, A. D. Barnes, N. Breidenbach, U. Brose, D. Buchori, R. Daniel, R. Finkeldey, I. Harahap, D. Hertel, A. M. Holtkamp, E. Hörandl, B. Irawan, I. N. S. Jaya, M. Jochum, B. Klarner, A. Knohl, M. M. Kotowska, V. Krashevska, H. Kreft,
S. Kurniawan, C. Leuschner, M. Maraun, D. N. Melati, N. Opfermann, C. Pérez-Cruzado, W. E. Prabowo, K. Rembold, A. Rizali, R. Rubiana, D. Schneider, S. S. Tjitrosoedirdjo, A. Tjoa, T. Tscharntke, and S. Scheu. 2016. Land-use choices follow profitability at the expense of ecological functions in Indonesian smallholder landscapes. Nature Communications 7:13137. https:// doi.org/10.1038/ncomms13137

Dang. N. M., M. S. Babel, and H. T. Luong. 2011. Evaluation of flood risk parameters in the Day River Flood Diversion Area, Red River Delta, Vietnam. Natural Hazards 56:169-194. https:// doi.org/10.1007/s11069-010-9558-X

de Blécourt, M., R. Brumme, J. Xu, M. D. Corre, and E. Veldkamp. 2013. Soil carbon stocks decrease following conversion of secondary forests to rubber (Hevea brasiliensis) plantations. PLoS ONE 8(7):e69357. https://doi.org/10.1371/ journal.pone.0069357

Di Baldassare, G., J. S. Kemerink, M. Kooy, and L. Brandimarte. 2014. Floods and societies: the spatial distribution of waterrelated disaster risk and its dynamics. WIREs Water 1(2):133-139. https://doi.org/10.1002/wat2.1015

Díaz, S., U. Pascual, M. Stenseke, B. Martín-López, R. T. Watson, Z. Molnár, R. Hill, K. M. A. Chan, I. A. Baste, K. A. Brauman, S. Polasky, A. Church, M. Lonsdale, A. Larigauderie, P. W. Leadley, A. P. E. van Oudenhoven, F. van der Plaat, M. Schröter, S. Lavorel, Y. Aumeeruddy-Thomas, E. Bukvareva, K. Davies, S. Demissew, G. Erpul, P. Failler, C. A. Guerra, C. L. Hewitt, H. Keune, S. Lindley, and Y. Shirayama. 2018. Assessing nature's contributions to people. Science 359(6373):270-272. https://doi. org/10.1126/science.aap8826

Don, A., J. Schumacher, and A. Freibauer. 2011. Impact of tropical land-use change on soil organic carbon stocks - a metaanalysis. Global Change Biology 17(4):1658-1670. https://doi. org/10.1111/j.1365-2486.2010.02336.X

Drescher, J., K. Rembold, K. Allen, P. Beckschäfer, D. Buchori, Y. Clough, H. Faust, A. M. Fauzi, D. Gunawan, D. Hertel, B. Irawan, I. N. S. Jaya, B. Klarner, C. Kleinn, A. Knohl, M. M. Kotowska, V. Krashevska, V. Krishna, C. Leuschner, W. Lorenz, A. Meijide, D. Melati, M. Nomura, C. Pérez-Cruzado, M. Qaim, I. Z. Siregar, S. Steinebach, A. Tjoa, T. Tscharntke, B. Wick, K. Wiegand, H. Kreft, and S. Scheu. 2016. Ecological and socioeconomic functions across tropical land use systems after rainforest conversion. Philosophical Transactions of the Royal Society B: Biological Sciences 371(1694):20150275. https://doi. org/10.1098/rstb.2015.0275

Ellison, D., C. E. Morris, B. Locatelli, D. Sheil, J. Cohen, D. Murdiyarso, V. Gutierrez, M. van Noordwijk, I. F. Creed, J. Pokorny, D. Gaveau, D. V. Spracklen, A. B. Tobella, U. Ilstedt, A. J. Teuling, S. G. Gebrehiwot, D. C. Sands, B. Muys, B. Verbist, E. Springgay, Y. Sugandi, and C. A. Sullivan. 2017. Trees, forests and water: cool insights for a hot world. Global Environmental Change 43(51):51-61. https://doi.org/10.1016/j.gloenvcha.2017.01.002

Evers, S., C. M. Yule, R. Padfield, P. O'Reilly, and H. Varkkey. 2017. Keep wetlands wet: the myth of sustainable development of tropical peatlands - implications for policies and management. Global Change Biology 23(2):534-549. https://doi.org/10.1111/ gcb. 13422 
Fabricius, C., R. Scholes, and G. Cundill. 2006. Mobilizing knowledge for integrated ecosystem assessments. Pages 165-182 in W. V. Reid, F. Berkes, T. Wilbanks, and D. Capistrano, editors. Bridging scales and knowledge systems: concepts and applications in ecosystem assessment. Island, Washington, USA.

Fearnside, P. M. 1997. Transmigration in Indonesia. Lessons from its environmental and social impacts. Environmental Management 21(4):553-570. https://doi.org/10.1007/s002679900049

Feintrenie, L., and P. Levang. 2009. Sumatra's rubber agroforests: advent, rise and fall of a sustainable cropping system. Small-scale Forestry 8(3):323-335. https://doi.org/10.1007/s11842-009-9086-2

Flick, U. 2016. Qualitative Sozialforschung. Rowohlt, Hamburg, Germany.

Forsyth, T. 2003. Critical political ecology: the politics of environmental science. Routledge, London, UK. https://doi. org/10.4324/9780203017562

Ge, F., S. Zhu, T. Peng, Y. Zhao, F. Sielman, K. Fraedrich, X. Zhi, X. Liu, W. Tang, and L. Ji. 2019. Risks of precipitation extremes over Southeast Asia: does $1.5^{\circ} \mathrm{C}$ or $2^{\circ} \mathrm{C}$ global warming make a difference? Environmental Research Letters 14:4. https://doi. org/10.1088/1748-9326/aaff7e

Gilbert, R. O. 1987. Statisticalmethods for environmental pollution monitoring. Wiley, New York, New York, USA.

Guillaume, T., M. Damris, and Y. Kuzyakov. 2015. Losses of soil carbon by converting tropical forest to plantations: erosion and decomposition estimated by $\delta{ }^{13} \mathrm{C}$. Global Change Biology 21 (9):3548-3560. https://doi.org/10.1111/gcb.12907

Guillaume, T., A. M. Holtkamp, M. Damris, B. Brümmer, and Y. Kuzyakov. 2016. Soil degradation in oil palm and rubber plantations under land resource scarcity. Agriculture, Ecosystems \& Environment 232:110-118. https://doi.org/10.1016/j.agee.2016.07.002

Gumbricht, T., R. M. Roman-Cuesta, L. Verchot, M. Herold, F. Wittmann, E. Householder, N. Herold, and D. Murdiyarso. 2017. An expert system model for mapping tropical wetlands and peatlands reveals South America as the largest contributor. Global Change Biology 23(9):3581-3599. https://doi.org/10.1111/gcb.13689

Hansen, M. C., P. V. Potapov, R. Moore, M. Hancher, S. A. Turubanova, A. Tyukavina, D. Thau, S. V. Stehman, S. J. Goetz, T. R. Loveland, A. Kommareddy, A. Egorov, L. Chini, C. O. Justice, and J. R. G. Townshend. 2013. High-resolution global maps of 21st-century forest cover change. Science 342 (6160):850-853. https://doi.org/10.1126/science.1244693

Hassler, S. K., B. Zimmermann, M. van Breugel, J. S. Hall, and H. Elsenbeer. 2011. Recovery of saturated hydraulic conductivity under secondary succession on former pasture in the humid tropics. Forest Ecology and Management 261(10):1634-1642. https://doi.org/10.1016/j.foreco.2010.06.031

Hofer, T., and B. Messerli. 2006. Floods in Bangladesh: history, dynamics and rethinking the role of the Himalayas. United Nations University Press, Tokyo, Japan.

Hooijer, A., R. Vernimmen, M. Visser, and N. Mawdsley. 2015. Flooding projections from elevation and subsidence models for oil palm plantations in the Rajang Delta peatlands, Sarawak,
Malaysia. Report 1207384. Deltares, Delft, The Netherlands. [online] URL: https://www.deltares.nl/app/uploads/2015/06/ Rajang-Delta-Peatland-Subsidence-Flooding-Deltares-2015.pdf

Houde, N. 2007. The six faces of traditional ecological knowledge: challenges and opportunities for Canadian co-management arrangements. Ecology and Society 12(2):34. https://doi. org/10.5751/ES-02270-120234

Ilstedt, U., A. Malmer, E. Verbeeten, and D. Murdiyarso. 2007. The effect of afforestation on water infiltration in the tropics: a systematic review and meta-analysis. Forest Ecology and Management 251(1-2):45-51. https://doi.org/10.1016/j.foreco.2007.06.014

Jambi Provincial Government (Pemertina Provinsi Jambi). 2016. Rencana Pembangunan Jangka Menengah Daerah (RPJMD) Provinsi Jambi 2016-2021. Provincial Government Jambi, Indonesia. [online] URL: http://jdih.jambiprov.go.id/ fileperaturan/6081Perda NO.7RPJMD 2016-2021.pdf

Junk, W., P. B. Bayley, and R. E. Sparks. 1989. The flood pulse concept in river-floodplain systems. Pages 110-127 in D. P. Dodge, editor. Proceedings of the International Large River Symposium ( $L A R S$ ). Canadian Special Publication of Fisheries and Aquatic Sciences 106:110-127.

Junk, W. J., and K. M. Wantzen. 2004. The flood pulse concept: new aspects, approaches and applications-an update. Pages 117-140 in R. L. Welcomme and T. Petr, editors. Proceedings of the Second International Symposium on the Management of Large Rivers for Fisheries. Volume 2. RAP Publication 2004/17. Food and Agriculture Organization of the United Nations (FAO) and the Mekong River Commission (MRC), FAO Regional Office for Asia and the Pacific, Bangkok, Thailand.

Kelley, L. S., and A. Prabowo. 2019. Flooding and land-use change in Southeast Sulawesi, Indonesia. Land 8(9):139. https:// doi.org/10.3390/land8090139

Klubnikin, K., C. Annett, M. Cherkasova, M. Shishin, and I. Fotieva. 2000. The sacred and the scientific: traditional ecological knowledge in Siberian river conservation. Ecological Applications 10:1296-1306. https://doi.org/10.1890/1051-0761(2000)010[1296: TSATST]2.0.CO;2

Krüger, T., C. Maynard, G. Carr, A. Bruns, E. N. Mueller, and S. Lane. 2016. A transdisciplinary account of water research. WIREs Water 3(3):369-389. https://doi.org/10.1002/wat2.1132

Kunz, Y. 2016. Landscape transformation in Jambi province, Sumatra. An analysis of land tenure regulations under translational dynamics. Dissertation. Georg-August University of Goettingen, Goettingen, Germany. [online] URL: https://ediss.uni-goettingen. de/handle/11858/00-1735-0000-0028-875A-A

Kwak, Y. 2017. Nationwide flood monitoring for disaster risk reduction using multiple satellite data. International Journal of Geo-Information 6(7):203. https://doi.org/10.3390/ijgi6070203

Langill, J. C., and C. Abizaid. 2020. What is a bad flood? Local perspectives of extreme floods in the Peruvian Amazon. Ambio 49:1423-1436. https://doi.org/10.1007/s13280-019-01278-8

Larsen, R. K., N. Jiwan, A. Rompas, J. Jenito, M. Osbeck, and A. Tarigan. 2014. Towards 'hybrid accountability' in EU biofuels policy? Community grievances and competing water claims in the 
Central Kalimantan oil palm sector. Geoforum 54:295-305. http:// dx.doi.org/10.1016/j.geoforum.2013.09.010

Laumonier, Y., 1997. The vegetation and physiography of Sumatra. Kluwer Academic, Dordrecht, The Netherlands. https://doi. org/10.1007/978-94-009-0031-8

Lawrence, D., and K. Vandecar. 2015. Effects of tropical deforestation on climate and agriculture. Nature Climate Change 5(1):27-36. https://doi.org/10.1038/nclimate2430

Leimona, B., B. Lusiana, M. van Noordwijk, E. Mulyoutami, A. Ekadinata, and S. Amaruzaman. 2015. Boundary work: knowledge co-production for negotiating payment for watershed services in Indonesia. Ecosystem Services 15:45-62. https://doi. org/10.1016/j.ecoser.2015.07.002

Lele, S. 2009. Watershed services of tropical forests: from hydrology to economic valuation to integrated analysis. Current Opinion in Environmental Sustainability 1(2):148-155. https://doi. org/10.1016/j.cosust.2009.10.007

Lele, S., and A. Kurien. 2011. Interdisciplinary analysis of the environment: insights from tropical forest research. Environmental Conservation 38(2):211-233. https://doi.org/10.1017/S037689291100018X

Li, H., Y. Ma, W. Liu, and W. Liu. 2012. Soil changes induced by rubber and tea plantation establishment: comparison with tropical rain forest soil in Xishuangbanna, SW China. Environmental Management 50(5):837-848. https://doi.org/10.1007/ s00267-012-9942-2

Locatelli, B., and R. Vignola. 2009. Managing watershed services of tropical forests and plantations: can meta-analyses help? Forest Ecology and Management 258(9):1864-1870. https://doi. org/10.1016/j.foreco.2009.01.015

Luke, S. H., H. Barclay, K. Bidin, V. K. Chey, R. M. Ewers, W. A. Foster, A. Nainar, M. Pfeifer, G. Reynolds, E. C. Turner, R. P. D. Walsh, and D. C. Aldridge. 2017. The effects of catchment and riparian forest quality on stream environmental conditions across a tropical rainforest and oil palm landscape in Malaysian Borneo. Ecohydrology 10:e1827. https://doi.org/10.1002/eco.1827

Maggioni, V., and C. Massari. 2018. On the performance of satellite precipitation products in riverine flood modeling: a review. Journal of Hydrology 558:214-224. https://doi. org/10.1016/j.jhydrol.2018.01.039

Malaysian Department of Irrigation and Drainage (MDID). 1989. Variation of rainfall with area in peninsular Malaysia. Sungai Tekam Experimental Basin Final Report, July 1977 to June 1986. Water Resources Publication 20. Malaysian Department of Irrigation and Drainage, Jakarta, Indonesia. [online] URL: https://www.water.gov.my/jps/resources/auto $\% 20$ download $\%$ 20images/58746b0be2b8a.pdf

Manoli, G., A. Meijide, N. Huth, A. Knohl, Y. Kosugi, P. Burlando, J. Ghazoul, and S. Fatichi. 2018. Ecohydrological changes after tropical forest conversion to oil palm. Environmental Research Letters 13:6. https://doi.org/10.1088/1748-9326/aac54e

Margono, B. A., P. V. Potapov, S. Turubanova, F. Stolle, and M. C. Hansen. 2014. Primary forest cover loss in Indonesia over 2000-2012. Nature Climate Change 4:730-735. https://doi. org/10.1038/nclimate2277
Margono, B. A., A. B. Usman, Budiharto, and R. A. Sugardiman. 2016. Indonesia's forest resource monitoring. Indonesian Journal of Geography 48(1):7-20. https://doi.org/10.22146/ijg.12496

Martens, K. 2017. Adaption strategies of oil palm smallholders towards certification schemes. A micro scale approach from Jambi, Sumatra. Thesis. Georg-August University of Goettingen, Goettingen, Germany. [online] URL: https://www.uni-goettingen. de/de/master+studies $+\mathrm{g} \% \mathrm{c} 3 \%$ b6ttingen $+\% 282017 \% 29 / 564021$.html

Mayring, P. 2000. Qualitative content analysis. Forum: Qualitative Social Research 1(2):20. https://doi.org/10.17169/fqs-1.2.1089

Melati, D. N. 2017. The use of remote sensing data to monitor land use systems and forest variables of the tropical rainforest landscape under transformation in Jambi Province, Sumatra, Indonesia. Dissertation. Georg-August-University of Goettingen, Goettingen, Germany. [online] URL: http://hdl.handle.net/11858/00-1735-0000-002EE323-E

Merten, J., A. Röll, T. Guillaume, A. Meijide, S. Tarigan, H. Agusta, C. Dislich, C. Dittrich, H. Faust, D. Gunawan, J. Hein, Hendrayanto, A. Knohl, Y. Kuzyakov, K. Wiegand, and D. Hölscher. 2016. Water scarcity and oil palm expansion: social views and environmental processes. Ecology and Society 21(2):5. http://dx.doi.org/10.5751/ES-08214-210205

Minister of Public Works (Menteri Pekerjaan Umum), Republic of Indonesia. 2012. Keputusan Menteri PU Nomor 51/KPTS/ M/2012 tentang Pola Pengelolaan Sumber Daya Air Wilayah Sungai Batanghari. Minister of Public Works, Jakarta, Indonesia. [online] URL: http://sda.pu.go.id/produk/mfhandler.php?file=2012_Pola $\%$ 20PSDA $\%$ 20Batanghari.pdf \&table $=$ newsmain $\&$ field $=$

Attachment\&pageType $=$ list \&key $1=140$

Mitsch, W. J., and J. G. Gosselink. 2015. Wetlands. Fifth edition. Wiley, Hobokoen, The Netherlands.

Moller, H., F. Berkes, P. O. Lyver, and M. Kislalioglu. 2004. Combining science and traditional ecological knowledge: monitoring populations for co-management. Ecology and Society 9(3):2. http://dx.doi.org/10.5751/ES-00675-090302

Nadasdy, P. 1999. The politics of TEK: power and the "integration" of knowledge. Arctic Anthropology 36:1-18.

NASA FIRMS. 2019. VIIRS active fires. [online] URL: www. globalforestwatch.org/map

Notti, D., D. Giordan, F. Caló, A. Pepe, F. Zucca, and J. P. Galve. 2018. Potential and limitations of open satellite data for flood mapping. Remote Sensing 10(11):1673. https://doi.org/10.3390/ $\underline{\text { rs10111673 }}$

Obidzinski, K., R. Andriani, H. Komarudin, and A. Andrianto. 2012. Environmental and social impacts of oil palm plantations and their implications for biofuel production in Indonesia. Ecology and Society 17(1):25. http://dx.doi.org/10.5751/ ES-04775-170125

Pachepsky, Y., and Y. Park. 2015. Saturated hydraulic conductivity of US soils grouped according to textural class and bulk density. Soil Science Society of America Journal 79 (4):1094-1100. https://doi.org/10.2136/sssaj2015.02.0067

Page, S. E., J. O. Rieley, and R. Wiist. 2006. Lowland tropical peatlands of Southeast Asia. Page 145-172 in I. P. Martini, A. 
Martinez Cortizas, and W. Chesworth, editors. Peatlands: evolution and records of environmental and climate changes. Development in Earth's surface processes 9. Elsevier, Amsterdam, The Netherlands. https://10.1016/S0928-2025(06)09007-9 https:// doi.org/10.1016/s0928-2025(06)09007-9

Pattison, I., and S. N. Lane. 2012. The link between land-use management and fluvial flood risk: a chaotic conception? Progress in Physical Geography 36(1):72-92. https://doi. org/10.1177/0309133311425398

Persson, J., E. L. Johansson, and L. Olsson. 2018. Harnessing local knowledge for scientific knowledge production: challenges and pitfalls within evidence-based sustainability studies. Ecology and Society 23(4):38. https://doi.org/10.5751/ES-10608-230438

Pierotti, R., and D. Wildcat. 2000. Traditional ecological knowledge: the third alternative (commentary). Ecological Applications 10(5):1333-1340. https://doi.org/10.1890/1051-0761 (2000)010[1333:TEKTTA]2.0.CO:2

Ramsar Convention Secretariat. 2016. An introduction to the Convention on Wetlands. Ramsar Convention Secretariat, Gland, Switzerland. [online] URL: https://www.ramsar.org/sites/default/ files/documents/library/handbook1 5ed introductiontoconvention e. pdf

Ribot, J. 2014. Cause and response: vulnerability and climate in the Anthropocene. Journal of Peasant Studies 41(5):667-705. https://doi.org/10.1080/03066150.2014.894911

Rödel, I. 2018. Smallholders' sustainability perceptions vs. performance in the context of Indonesian palm oil. How do international sustainability criteria influence local discourses and practices in rural Sumatra? Thesis. Georg-August University of Goettingen, Goettingen, Germany. [online] URL: https://www. uni-goettingen.de/de/master + studies $+\mathrm{g} \% \mathrm{c} 3 \% \mathrm{~b} 6 \mathrm{ttingen}+\% 282018 \%$ 29/583178.html

Röll, A., F. Niu, A. Mejide, J. Ahongshangbam, M. Ehbrecht, T. Guillaume, D. Gunawan, A. Hardanto, Hendrayanto, D. Hertel, M. M. Kotowska, H. Kreft, Y. Kuzyakov, C. Leuschner, M. Nomura, A. Polle, K. Rembold, J. Sahner, D. Seidel, D. C. Zemp, A. Knohl, and D. Hölscher. 2019. Transpiration on the rebound in lowland Sumatra. Agricultural and Forest Meteorology 274:160-171. https://doi.org/10.1016/j.agrformet.2019.04.017

Roni, P., editor. 2005. Monitoring stream and water restoration. American Fisheries Society, Bethesda, Maryland, USA.

Saberwal, V. K. 1998. Science and the desiccationist discourse of the 20th century. Environment and History 4(3):309-343. https:// doi.org/10.3197/096734098779555547

Saputra, D. 2017. Jambi berstatus siaga III banjir. Antara Jambi, 12 March. [online] URL: https://jambi.antaranews.com/ berita/318040/jambi-berstatus-siaga-iii-banjir

Schoneveld, G. C., D. Ekowati, A. Andrianto, and S. van der Haar. 2019. Modeling peat- and forestland conversion by oil palm smallholders in Indonesian Borneo. Environmental Research Letters 14:1. https://doi.org/10.1088/1748-9326/aaf044

Spracklen, D. V., J. C. A. Baker, L. Garcia-Carreras, and J. H. Marsham. 2018. The effects of tropical vegetation on rainfall.
Annual Review of Environment and Resources 43:193-218. https:// doi.org/10.1146/annurev-environ-102017-030136

Stringer, L. C., and M. S. Reed. 2007. Land degradation assessment in Southern Africa: integrating local and scientific knowledge bases. Land Degradation \& Development 18(1):99-116. https://doi.org/10.1002/1dr.760

Sumarga, E., L. Hein, A. Hooijer, and R. Vernimmen. 2016. Hydrological and economic effects of oil palm cultivation in Indonesian peatlands. Ecology and Society 21(2):52 http://dx.doi. org/10.5751/ES-08490-210252

Tan-Soo, J.-S., N. Adnan, I. Ahmad, S. K. Pattanayak, and J. R. Vincent. 2016. Econometric evidence on forest ecosystem services: deforestation and flooding in Malaysia. Environmental and Resource Economics 63:25-44. https://doi.org/10.1007/ s10640-014-9834-4

Tarigan, S., K. Wiegand, Sunarti, and B. Slamet. 2018. Minimum forest cover required for sustainable water flow regulation of a watershed: a case study in Jambi Province, Indonesia. Hydrology and Earth System Sciences 22:581-594. https://doi.org/10.5194/ hess-22-581-2018

Tengö, M., E. S. Brondizio, T. Elmqvist, P. Malmer, and M. Spierenburg. 2014. Connecting diverse knowledge systems for enhanced ecosystem governance: the multiple evidence bBase approach. Ambio 43:579-591. https://doi.org/10.1007/s13280-014-0501-3

Teuscher, M., A. Gérard, U. Brose, D. Buchori, Y. Clough, M. Ehbrecht, D. Hölscher, B. Irawan, L. Sundawati, M. Wollni, and H. Kreft. 2016. Experimental biodiversity enrichment in oilpalm-dominated landscapes in Indonesia. Frontiers in Plant Science 7:1538. https://doi.org/10.3389/fpls.2016.01538

The Jakarta Post. 2014. Floods ruin thousands of hectares of crops. The Jakarta Post, 31 December. [online] URL: https://www. thejakartapost.com/news/2014/12/31/floods-ruin-thousands-hectarescrops.html

Thorén, H., and J. Persson. 2013. The philosophy of interdisciplinarity: sustainability science and problem-feeding. Journal for General Philosophy of Science 44:337-355. https://doi. org/10.1007/s10838-013-9233-5

Thorén, H., and S. Stahlhammer. 2018. Ecosystem services between integration and economic imperialism. Ecology and Society 23(4):44. https://doi.org/10.5751/ES-10520-230444

Townend, J. 2004. Practical statistics for environmental and biological scientists. Third edition. John Wiley \& Sons, Chichester, UK.

Tran, P., F. Marincioni, and R. Shaw. 2010. Catastrophic flood and forest cover change in the Huong river basin, central Viet Nam: a gap between common perceptions and facts. Journal of Environmental Management 91(11):2186-2200. https://doi. org/10.1016/j.jenvman.2010.05.020

Uryu, Y., E. Purastuti, Y. Laumonier, Sunarto, Setiabudi, A. Budiman, K. Yulianto, A. Sudibyo, O. Hadian, D. A. Kosasih, and A. Stüwe. 2010. Sumatra's forests, their wildlife and the climate windows in time: 1985, 1990, 2000 and 2009. Technical Report. WWF Indonesia, Jakarta, Indonesia. 
Usher, P. J. 2000. Traditional ecological knowledge in environmental assessment and management. Arctic 53 (2):183-193. http://doi.org/10.14430/arctic849

van Dijk, A. I. J. M., M. van Noordwijk, I. R. Calder, Sampurno, L. A. Bruijnzeel, J. Schellekens, and N. A. Chappell. 2009. Forestflood relation still tenuous - comment on 'Global evidence that deforestation amplifies flood risk and severity in the developing world' by C. J. A. Bradshaw, N. S. Sodi, K. S.-H. Peh and B.W. Brook. Global Change Biology 15(1):110-115. https://doi. org/10.1111/j.1365-2486.2008.01708.x

Wahyunto, R. S., and H. Subagjo. 2003. Peta Luas Sebaran Lahan Gambut dan Kandungan Karbon di Pulau Sumatera / Maps of peatland distribution and carbon content in Sumatera, 1990-2002. Wetlands International Indonesia Programme and Wildlife Habitat Canada (WHC), Bogor, Indonesia.

Waite, P.-A., B. Schuldr, R. M. Link, N. Breidenbach, T. Triadiati, N. Hennings, A. Saad, and C. Leuschner. 2019. Soil moisture regime and palm height influence embolism resistance in oil palm. Tree Physiology 39(10):1696-1712. $\underline{\text { https://doi.org/10.1093/ }}$ treephys/tpz061

Walters, B. B., and A. P. Vayda. 2009. Event ecology, causal historical analysis, and human-environment research. Annals of the Association of American Geographers 99(3):534-553. https:// doi.org/10.1080/00045600902931827

Wang, H., Z. Yang, Y. Saito, J. P. Liu, and X. Sun. 2006. Interannual and seasonal variation of the Huanghe (Yellow River) water discharge over the past 50 years: connections to impacts from ENSO events and dams. Global and Planetary Change 50:212-225. https://doi.org/10.1016/j.gloplacha.2006.01.005

Wang. L., X. Chen, Q. Shao, and Y. Li. 2015. Flood indicators and their clustering features in Wujiang River, South China. Ecological Engineering 76:66-74. http://dx.doi.org/10.1016/j. ecoleng.2014.03.018

Wantzen, K. M., and J. H. Mol. 2013. Soil erosion from agriculture and mining: a threat to tropical stream ecosystems. Agriculture 3:660-683. https://doi.org/10.3390/agriculture3040660

Wells, J. A., K. A. Wilson, N. K. Abram, M. Nunn, D. L. A. Gaveau, R. K. Runting, N. Tarniati, K. L. Mengersen, and E. Meijaard. 2016. Rising floodwaters: mapping impacts and perceptions of flooding in Indonesian Borneo. Environmental Research Letters 11(6):064016. https://doi.org/10.1088/1748-932$\underline{6 / 11 / 6 / 064016}$

Wösten, J. H. M., E. Clymans, S. E. Page, J. O. Rieley, and S. H. Limin. 2008. Peat-water interrelationships in a tropical peatland ecosystem in Southeast Asia. CATENA 73(2):212-224. https:// doi.org/10.1016/j.catena.2007.07.010

Wösten, J. H. M., J. Van Den Berg, P. van Eijk, G. J. M. Gevers, W. B. J. T. Giesen, A. Hooijer, A. Idris, P. H. Leenman, D. S. Rais, C. Siderius, M. J. Silvius, N. Suryadiputra, and I. T. Wibisono. 2006. Interrelationships between hydrology and ecology in fire degraded tropical peat swamp forests. International Journal of Water Resources Development 22(1):157-174. https://doi. org/10.1080/07900620500405973
Yeung, H. W. 1997. Critical realism and realist research in human geography: a method or a philosophy in search of a method? Progress in Human Geography 21(1):51-74. https://doi. org/10.1191/030913297668207944

Yusop, Z., C. H. Chan, and A. Katimon. 2007. Runoff characteristics and application of HEC-HMS for modelling stormflow hydrograph in an oil palm catchment. Water Science \& Technology 56(8):41-48. https://doi.org/10.2166/wst.2007.690

Zhang, Q., C.-Y. Xu, S. Becker, Z. X. Zhang, Y. D. Chen, and M. Coulibaly. 2009. Trends and abrupt changes of precipitation maxima in the Pearl River basin, China. Atmospheric Science Letters 10:132-144. https://doi.org/10.1002/as1.221

Zhang, X., L. Alexander, G. C. Hegerl, P. Jones, A. K. Tank, T. C. Peterson, B. Trewin, and F. W. Zwiers. 2011. Indices for monitoring changes in extremes based on daily temperature and precipitation data. WIREs Climate Change 2(6):851-870. https:// doi.org/10.1002/wcc.147

Ziegler, A. D., J. Negishi, R. C. Sidle, P. Preechapanya, R. A. Sutherland, T. W. Giambelluca, and S. Jaiaree. 2006. Reduction of stream sediment concentration by a riparian buffer: filtering of rad runoff in disturbed headwater basins of montane mainland Southeast Asia. Journal of Environmental Quality 35(1):151-162. https://doi.org/10.2134/jeq2005.0103 
Appendix 1: Biodiversity enrichment experiment

Table A1.1: Information regarding the plots of the biodiversity enrichment experiment (EFForTS-BEE) where water infiltration has been measured. Details on the species composition, plot size and tree diversity are described in Teuscher et al. (2016). A: Parkia speciosa (Fabaceae); B: Archidendron pauciflorum (Fabaceae); C: Durio zibethinus (Malvaceae); D: Dyera polyphylla (Apocynaceae); E: Peronema canescens (Lamiaceae); F: Shorea leprosula (Dipterocarpaceae)

\begin{tabular}{|c|c|c|c|c|c|c|}
\hline Plot ID & Lat & Long & Plot size & $\begin{array}{l}\text { Diversity } \\
\text { Level }\end{array}$ & $\begin{array}{l}\text { Composition } \\
\text { of the planted } \\
\text { tree species }\end{array}$ & $\begin{array}{l}\text { Number of } \\
\text { planted } \\
\text { trees }\end{array}$ \\
\hline 1 & -1.94162 & 103.2519 & 40 & 1 & $\mathrm{~A}$ & 400 \\
\hline 2 & -1.94174 & 103.253 & 20 & 3 & $\mathrm{ACF}$ & 99 \\
\hline 3 & -1.9433 & 103.2518 & 20 & 2 & $\mathrm{CD}$ & 100 \\
\hline 4 & -1.94321 & 103.2532 & 10 & 1 & $\mathrm{~F}$ & 25 \\
\hline 5 & -1.94478 & 103.2518 & 40 & 1 & B & 400 \\
\hline 6 & -1.94462 & 103.2532 & 5 & 1 & $\mathrm{E}$ & 6 \\
\hline 7 & -1.94469 & 103.2552 & 40 & 3 & $\mathrm{AEF}$ & 399 \\
\hline 8 & -1.94587 & 103.2491 & 5 & 1 & $\mathrm{~F}$ & 6 \\
\hline 12 & -1.94589 & 103.2543 & 20 & 1 & $\mathrm{C}$ & 100 \\
\hline 13 & -1.94591 & 103.2559 & 10 & 1 & E & 25 \\
\hline 17 & -1.94734 & 103.2531 & 20 & 1 & $\mathrm{~F}$ & 100 \\
\hline 22 & -1.94873 & 103.2491 & 5 & 2 & $\mathrm{BF}$ & 6 \\
\hline 24 & -1.94838 & 103.2543 & 40 & 2 & $\mathrm{CE}$ & 400 \\
\hline 26 & -1.94849 & 103.2572 & 40 & 2 & $\mathrm{DF}$ & 400 \\
\hline 27 & -1.94992 & 103.2464 & 10 & 2 & $\mathrm{AE}$ & 24 \\
\hline 28 & -1.95002 & 103.2478 & 5 & 1 & $\mathrm{~B}$ & 6 \\
\hline 29 & -1.94996 & 103.249 & 40 & 3 & $\mathrm{BCD}$ & 399 \\
\hline 30 & -1.94981 & 103.253 & 20 & 1 & $\mathrm{E}$ & 100 \\
\hline 31 & -1.94997 & 103.2545 & 5 & 1 & $\mathrm{C}$ & 6 \\
\hline 34 & -1.95143 & 103.2451 & 10 & 2 & $\mathrm{BD}$ & 24 \\
\hline 35 & -1.95182 & 103.2466 & 40 & 0 & $\mathrm{Z}$ & 0 \\
\hline 36 & -1.95106 & 103.2477 & 20 & 2 & $\mathrm{AF}$ & 100 \\
\hline 37 & -1.95118 & 103.2488 & 10 & 0 & $\mathrm{Z}$ & 0 \\
\hline 38 & -1.95172 & 103.2504 & 20 & 1 & $\mathrm{D}$ & 100 \\
\hline 39 & -1.95138 & 103.2518 & 5 & 2 & $\mathrm{AC}$ & 6 \\
\hline 41 & -1.95267 & 103.2438 & 10 & 1 & A & 25 \\
\hline 42 & -1.95276 & 103.245 & 5 & 1 & $\mathrm{D}$ & 6 \\
\hline 44 & -1.95271 & 103.2478 & 5 & 3 & BEF & 6 \\
\hline 45 & -1.95307 & 103.2487 & 40 & 1 & E & 400 \\
\hline 46 & -1.95442 & 103.2424 & 40 & 2 & $\mathrm{AB}$ & 400 \\
\hline 47 & -1.95395 & 103.2437 & 20 & 2 & $\mathrm{BE}$ & 100 \\
\hline 48 & -1.9541 & 103.2452 & 10 & 3 & CEF & 24 \\
\hline 49 & -1.954 & 103.2466 & 40 & 1 & $\mathrm{~F}$ & 400 \\
\hline
\end{tabular}




\begin{tabular}{|c|c|c|c|c|c|c|}
\hline 50 & -1.95406 & 103.2478 & 5 & 6 & ABCDEF & 6 \\
\hline 51 & -1.95425 & 103.2491 & 20 & 1 & A & 100 \\
\hline 53 & -1.94325 & 103.2547 & 10 & control & & 0 \\
\hline 54 & -1.9512 & 103.2558 & 10 & control & & 0 \\
\hline 55 & -1.9513 & 103.2534 & 10 & control & & 0 \\
\hline 56 & -1.95505 & 103.2461 & 10 & control & & 0 \\
\hline
\end{tabular}




\section{Appendix 2: River discharge}

Table A2.1: Mean water level ( \pm standard deviation) at Pauh hydrological station and results of Mann-Kendall test (Mann-Kendall $\tau$ and $p$ value).

\begin{tabular}{|c|c|c|c|c|c|c|c|c|c|c|c|c|c|c|c|}
\hline \multirow{2}{*}{ Year } & \multicolumn{12}{|c|}{ Month } & \multirow{2}{*}{$\begin{array}{c}\text { Wet } \\
\text { season } \\
\text { (Oct.- } \\
\text { May) }\end{array}$} & \multirow{2}{*}{$\begin{array}{c}\text { Dry } \\
\text { season } \\
\text { (Jun.- } \\
\text { Sept.) }\end{array}$} & \multirow{2}{*}{ Annual } \\
\hline & Jan. & Feb. & Mar. & Apr. & May & Jun. & Jul. & Aug. & Sept. & Oct. & Nov. & Dec. & & & \\
\hline $\begin{array}{c}\text { Average } \\
(1997- \\
2016) \\
\end{array}$ & $\begin{array}{c}7.07 \\
( \pm 2.05)\end{array}$ & $\begin{array}{c}6.90 \\
( \pm 2.24)\end{array}$ & $\begin{array}{c}6.80 \\
( \pm 2.46)\end{array}$ & $\begin{array}{c}7.25 \\
( \pm 2.17)\end{array}$ & $\begin{array}{c}6.47 \\
( \pm 1.94)\end{array}$ & $\begin{array}{c}4.92 \\
( \pm 1.50)\end{array}$ & $\begin{array}{c}4.74 \\
( \pm 1.58)\end{array}$ & $\begin{array}{c}4.48 \\
( \pm 1.29)\end{array}$ & $\begin{array}{c}4.43 \\
( \pm 1.32)\end{array}$ & $\begin{array}{c}5.08 \\
( \pm 1.43)\end{array}$ & $\begin{array}{c}7.05 \\
( \pm 1.73)\end{array}$ & $\begin{array}{c}8.13 \\
( \pm 2.67)\end{array}$ & $\begin{array}{c}6.88 \\
( \pm 1.47)\end{array}$ & $\begin{array}{c}4.98 \\
( \pm 1.22)\end{array}$ & $\begin{array}{c}6.07 \\
( \pm 1.29)\end{array}$ \\
\hline $\begin{array}{c}\text { Mann- } \\
\text { Kendall } \\
\tau\end{array}$ & $\begin{array}{c}0.13 \\
(p<0.001)\end{array}$ & $\begin{array}{c}0.23 \\
(p<0.001)\end{array}$ & $\begin{array}{c}0.22 \\
(p<0.001)\end{array}$ & $\begin{array}{c}0.33 \\
(p<0.001)\end{array}$ & $\begin{array}{c}0.28 \\
(p<0.001)\end{array}$ & $\begin{array}{c}0.25 \\
(p<0.001)\end{array}$ & $\begin{array}{c}0.21 \\
(p<0.001)\end{array}$ & $\begin{array}{c}0.05 \\
(p=0.07)\end{array}$ & $\begin{array}{c}0.05 \\
(p=0.07)\end{array}$ & $\begin{array}{c}-0.14 \\
(p<0.001)\end{array}$ & $\begin{array}{c}0.26 \\
(p<0.001)\end{array}$ & $\begin{array}{c}0.25 \\
(p<0.001)\end{array}$ & $\begin{array}{c}0.29 \\
(p<0.001)\end{array}$ & $\begin{array}{c}0.14 \\
(p<0.05)\end{array}$ & $\begin{array}{c}0.18 \\
(p<0.001)\end{array}$ \\
\hline
\end{tabular}

Table A2.2: Sum of days with water level $>11 \mathrm{~m}$ at Pauh hydrological station and results of Mann-Kendall test (Mann-Kendall $\tau$ and $p$-value).

\begin{tabular}{|c|c|c|c|c|c|c|c|c|c|c|c|c|c|c|c|}
\hline \multirow{2}{*}{ Year } & \multicolumn{12}{|c|}{ Month } & \multirow{2}{*}{$\begin{array}{c}\text { Wet } \\
\text { season } \\
\text { (Oct.- } \\
\text { May) }\end{array}$} & \multirow{2}{*}{$\begin{array}{c}\text { Dry } \\
\text { season } \\
\text { (Jun.- } \\
\text { Sept.) } \\
\end{array}$} & \multirow{2}{*}{ Annual } \\
\hline & Jan. & Feb. & Mar. & Apr. & May & Jun. & Jul. & Aug. & Sept. & Oct. & Nov. & Dec. & & & \\
\hline $\begin{array}{c}\text { Average } \\
(1997- \\
2016) \\
\end{array}$ & $\begin{array}{c}1.8 \\
( \pm 1.6)\end{array}$ & $\begin{array}{c}2.5 \\
( \pm 3.1)\end{array}$ & $2( \pm 2.7)$ & $\begin{array}{c}2.2 \\
( \pm 2.4)\end{array}$ & $\begin{array}{c}1.8 \\
( \pm 1.0)\end{array}$ & 0 & 0 & 0 & 0 & 0.1 & $\begin{array}{c}1.4 \\
( \pm 0.7)\end{array}$ & $\begin{array}{c}3.6 \\
( \pm 4.3)\end{array}$ & $\begin{array}{c}15.4 \\
( \pm 1.0)\end{array}$ & 0 & $\begin{array}{c}15.4 \\
( \pm 1.0)\end{array}$ \\
\hline $\begin{array}{c}\text { Mann- } \\
\text { Kendall } \\
\tau\end{array}$ & $\begin{array}{c}0.49 \\
(p=0.01)\end{array}$ & $\begin{array}{c}0.28 \\
(p=0.15)\end{array}$ & $\begin{array}{c}0.24 \\
(p=0.21)\end{array}$ & $\begin{array}{c}0.23 \\
(p<0.24)\end{array}$ & $\begin{array}{c}0.23 \\
(p<0.23)\end{array}$ & - & - & - & - & $\begin{array}{c}0.32 \\
(p=0.12)\end{array}$ & $\begin{array}{c}0.59 \\
(p<0.01)\end{array}$ & $\begin{array}{c}0.25 \\
(p=0.17)\end{array}$ & $\begin{array}{c}0.45 \\
(p<0.01)\end{array}$ & $\begin{array}{c}0.32 \\
(p=0.12)\end{array}$ & $\begin{array}{c}0.45 \\
(p<0.01)\end{array}$ \\
\hline
\end{tabular}


Table A2.3: Average water level rise (m) ( \pm standard deviation), based on the difference between average water levels of two consecutive days at Pauh hydrological station and results of Mann-Kendall test (Mann-Kendall $\tau$ and $p$-value).

\begin{tabular}{|c|c|c|c|c|c|c|c|c|c|c|c|c|c|c|c|}
\hline \multirow{2}{*}{ Year } & \multicolumn{12}{|c|}{ Month } & \multirow{2}{*}{$\begin{array}{l}\text { Wet } \\
\text { season } \\
\text { (Oct.- } \\
\text { May) }\end{array}$} & \multirow{2}{*}{$\begin{array}{c}\text { Dry } \\
\text { season } \\
\text { (Jun.- } \\
\text { Sept.) }\end{array}$} & \multirow{2}{*}{ Annual } \\
\hline & Jan. & Feb. & Mar. & Apr. & May & Jun. & Jul. & Aug. & Sept. & Oct. & Nov. & Dec. & & & \\
\hline $\begin{array}{c}\text { Average } \\
(1997- \\
2016)\end{array}$ & $\begin{array}{c}0.43 \\
( \pm 0.15)\end{array}$ & $\begin{array}{c}0.50 \\
( \pm 0.22)\end{array}$ & $\begin{array}{c}0.46 \\
( \pm 0.16)\end{array}$ & $\begin{array}{c}0.43 \\
( \pm 0.24)\end{array}$ & $\begin{array}{c}0.51 \\
( \pm 0.32)\end{array}$ & $\begin{array}{c}0.43 \\
( \pm 0.21)\end{array}$ & $\begin{array}{c}0.37 \\
( \pm 0.14)\end{array}$ & $\begin{array}{c}0.40 \\
( \pm 0.30)\end{array}$ & $\begin{array}{c}0.41 \\
( \pm 0.30)\end{array}$ & $\begin{array}{c}0.42 \\
( \pm 0.26)\end{array}$ & $\begin{array}{c}0.47 \\
( \pm 0.16)\end{array}$ & $\begin{array}{c}0.53 \\
( \pm 0.22)\end{array}$ & $\begin{array}{c}0.46 \\
( \pm 0.10)\end{array}$ & $\begin{array}{c}0.42 \\
( \pm 0.13)\end{array}$ & $\begin{array}{c}0.45 \\
( \pm 0.10)\end{array}$ \\
\hline $\begin{array}{c}\text { Mann- } \\
\text { Kendall } \\
\tau\end{array}$ & $\begin{array}{c}0.22 \\
(p=0.21)\end{array}$ & $\begin{array}{c}0.56 \\
(p<0.01)\end{array}$ & $\begin{array}{c}0.35 \\
(p=0.05)\end{array}$ & $\begin{array}{c}0.22 \\
(p=0.21)\end{array}$ & $\begin{array}{c}0.29 \\
(p=0.09)\end{array}$ & $\begin{array}{c}0.14 \\
(p=0.44)\end{array}$ & $\begin{array}{c}0.12 \\
(p=0.54)\end{array}$ & $\begin{array}{c}0.06 \\
(p=0.77)\end{array}$ & $\begin{array}{c}0.15 \\
(p=0.40)\end{array}$ & $\begin{array}{c}-0.03 \\
(p=0.88)\end{array}$ & $\begin{array}{c}0.18 \\
(p=0.34)\end{array}$ & $\begin{array}{c}0.12 \\
(p=0.54)\end{array}$ & $\begin{array}{c}0.16 \\
(p<0.01)\end{array}$ & $\begin{array}{c}0.14 \\
(p<0.01)\end{array}$ & $\begin{array}{c}0.16 \\
(p<0.01)\end{array}$ \\
\hline
\end{tabular}


Appendix 3: Determination of flood-risk areas

In order to map areas that are prone to flooding, we followed the guidelines of the Indonesian National Agency for Disaster Management (Badan Nasional Penanggulangan Bencana / BNPB), which requires two main input datasets, namely (1) a digital elevation model (DEM) and $(2)$ the river flow network. We used the 3 arc-second $(\approx 90 \mathrm{~m})$ void-filled, open-access DEM "Hydrological Data and Maps Based on Shuttle Elevation Derivatives at Multiple Scales" (HydroSHEDS) developed by the Conservation Science Program of the World Wildlife Fund For Nature (Lehner et al. 2008). This DEM presents a combination of the Shuttle Radar Topography Mission (SRTM-3) and the void-filled digital terrain elevation data (DTED®-1) (Lehner 2013). The river network is based on the corresponding vector layer from the Indonesian Geospatial Information Agency (Badan Informasi Geospasial / BIG 2017) digitally available for Jambi Province at the scales of 1:250,000 and 1:50,000. Building on these two datasets, we determined a flooding probability by combining the slope gradient, distance from the rivers and the modified topographic index $\left(T I_{m}\right)$ :

$$
T I_{m}=\ln \left[\frac{a_{d}^{n}}{\tan (\beta)}\right]
$$

where $a_{d}$ is the local upslope contributing area per unit contour length; $\tan (\beta)$ is the local slope gradient; $n$ is an exponent $\left(0.016 \mathrm{x}^{0.46}\right)$ and $x$ is the spatial resolution of the DEM (Manfreda et al. 2011; Manfreda et al. 2014). The $\mathrm{TI}_{\mathrm{m}}$ was developed to delineate the exposure to flooding events on the basis of the basin topography (Manfreda et al. 2011). Eventually, an area was defined as flood-prone when (1) the distance to the river was $<300$ m, (2) the slope gradient $<15 \%$ and (3) $T I_{m}$ exceeded a threshold $\tau$, which was set to $\tau=$ $10.89 n+2.282$ (based on BNPB 2016), and constitutes an area that equals or exceeds $0.2 \%$ annual chance to be flooded (Holmes Jr. and Dinicola, 2010).

\section{LITERATURE CITED}

[BIG] Badan Informasi Geospasial / Indonesian Geospatial Information Agency. 2017. Peta Rupabumi. Retrieved from http://www.big.go.id/peta-rupabumi/.

[BNPB] Badan Nasional Penanggulangan Bencana / Indonesian National Agency for Disaster Management. 2016. Risiko Bencana Indonesia. Direktorat Pengurangan Risiko Bencana. Jakarta.

Holmes Jr., R.R., Dinicola, K. 2010. 100-year flood-it's all about chance. [online] URL: https://pubs.usgs.gov/gip/106/pdf/100-year-flood-handout-042610.pdf

Lehner, B., Verdin, K., and A. Jarvis. 2008. New global hydrography derived from spaceborne elevation data. Eos, Transactions, American Geophysical Union 89(10):93-94. https://doi.org/10.1029/2008EO100001 
Lehner, B. 2013. HydroSHEDS technical documentation version 1.2. Conservation Science Program World Wildlife Fund US.

Manfreda, S., Di Leo, M., and A. Sole. 2011. Detection of flood-prone areas using digital elevation models. Journal of Hydrologic Engineering 16(10):781-790. https://doi.org/10.1061/(ASCE)HE.1943-5584.0000367

Manfreda, S., Nardi, F., Samela, C., Grimaldi, S., Taramasso, A.C., Roth, G., and A. Sole. 2014. Investigation on the Use of Geomorphic Approaches for the Delineation of Flood Prone Areas, Journal of Hydrology. Journal of Hydrology 517: 863-876. https://doi.org/10.1016/j.jhydrol.2014.06.009 


\section{Appendix 4: Precipitation}

Table A4.1: Accumulated precipitation (mm) at Pauh meteorological station and results of Mann-Kendall test (Mann-Kendall $\tau$ and $p$-value).

\begin{tabular}{|c|c|c|c|c|c|c|c|c|c|c|c|c|c|c|c|}
\hline \multirow{2}{*}{ Year } & \multicolumn{12}{|c|}{ Month } & \multirow{2}{*}{$\begin{array}{l}\text { Wet } \\
\text { season } \\
\text { (Oct.- } \\
\text { May) }\end{array}$} & \multirow{2}{*}{$\begin{array}{c}\text { Dry } \\
\text { season } \\
\text { (Jun.- } \\
\text { Sept.) }\end{array}$} & \multirow{2}{*}{ Annual } \\
\hline & Jan. & Feb. & Mar. & Apr. & May & Jun. & Jul. & Aug. & Sept. & Oct. & Nov. & Dec. & & & \\
\hline $\begin{array}{c}\text { Average } \\
(2007- \\
2016) \\
\end{array}$ & $\begin{array}{c}290.3 \\
( \pm 115.9)\end{array}$ & $\begin{array}{c}216.7 \\
( \pm 74.1)\end{array}$ & $\begin{array}{c}268.5 \\
( \pm 149.3)\end{array}$ & $\begin{array}{c}280.3 \\
( \pm 94.6)\end{array}$ & $\begin{array}{c}244.1 \\
( \pm 83.9)\end{array}$ & $\begin{array}{c}109.6 \\
( \pm 53.0)\end{array}$ & $\begin{array}{c}170.6 \\
( \pm 94.0)\end{array}$ & $\begin{array}{c}126.6 \\
( \pm 85.2)\end{array}$ & $\begin{array}{c}141.2 \\
( \pm 112.1)\end{array}$ & $\begin{array}{c}256.1 \\
( \pm 110.3)\end{array}$ & $\begin{array}{c}352.7 \\
( \pm 119.4)\end{array}$ & $\begin{array}{l}365.0 \mathrm{~A}) \\
( \pm 162.8)\end{array}$ & $\begin{array}{c}1993.1 \\
( \pm 392.7)\end{array}$ & $\begin{array}{c}792.1 \\
( \pm 220.2)\end{array}$ & $\begin{array}{c}2785.2 \\
( \pm 547.0)\end{array}$ \\
\hline $\begin{array}{c}\text { Mann- } \\
\text { Kendall } \\
\tau\end{array}$ & $\begin{array}{c}0.16 \\
(p=0.59)\end{array}$ & $\begin{array}{c}0.38 \\
(p=0.15)\end{array}$ & $\begin{array}{c}0.33 \\
(p=0.21)\end{array}$ & $\begin{array}{c}0.20 \\
(p=0.47)\end{array}$ & $\begin{array}{c}0.60 \\
(p<0.05)\end{array}$ & $\begin{array}{c}-0.04 \\
(\mathrm{P}=0.93)\end{array}$ & $\begin{array}{c}-0.07 \\
(p=0.86)\end{array}$ & $\begin{array}{c}-0.20 \\
(p=0.47)\end{array}$ & $\begin{array}{c}-0.24 \\
(p=0.37)\end{array}$ & $\begin{array}{c}-0.33 \\
(p=0.21)\end{array}$ & $\begin{array}{c}0.56 \\
(p<0.05)\end{array}$ & $\begin{array}{c}0.06 \\
(p=0.92)\end{array}$ & $\begin{array}{c}0.02 \\
(p=0.13)\end{array}$ & $\begin{array}{c}-0.02 \\
(p=0.33)\end{array}$ & $\begin{array}{c}0.03 \\
(p=0.65)\end{array}$ \\
\hline
\end{tabular}

A) No data for December 2012 available

Table A4.2: Average precipitation intensity index ( \pm standard deviation) at Pauh meteorological station and results of Mann-Kendall test (MannKendall $\tau$ and $p$-value).

\begin{tabular}{|c|c|c|c|c|c|c|c|c|c|c|c|c|c|c|c|}
\hline \multirow{2}{*}{ Year } & \multicolumn{12}{|c|}{ Month } & \multirow{2}{*}{$\begin{array}{c}\text { Wet } \\
\text { season } \\
\text { (Oct.- } \\
\text { May) }\end{array}$} & \multirow{2}{*}{$\begin{array}{c}\text { Dry } \\
\text { season } \\
\text { (Jun.- } \\
\text { Sept.) } \\
\end{array}$} & \multirow{2}{*}{ Annual } \\
\hline & Jan. & Feb. & Mar. & Apr. & May & Jun. & Jul. & Aug. & Sept. & Oct. & Nov. & Dec. & & & \\
\hline $\begin{array}{l}2007- \\
2016\end{array}$ & $\begin{array}{c}15.9 \\
( \pm 13.3)\end{array}$ & $\begin{array}{c}17.6 \\
( \pm 13.5)\end{array}$ & $\begin{array}{c}17.2 \\
( \pm 16.1)\end{array}$ & $\begin{array}{c}22.0 \\
( \pm 19.0)\end{array}$ & $\begin{array}{c}21.6 \\
( \pm 21.2)\end{array}$ & $\begin{array}{c}13.7 \\
( \pm 13.5)\end{array}$ & $\begin{array}{c}18.5 \\
( \pm 22.5)\end{array}$ & $\begin{array}{c}15.4 \\
( \pm 16.5)\end{array}$ & $\begin{array}{c}17.3 \\
( \pm 16.9)\end{array}$ & $\begin{array}{c}17.1 \\
( \pm 14.0)\end{array}$ & $\begin{array}{c}24.4 \\
( \pm 22.4)\end{array}$ & $\begin{array}{c}23.3 \\
( \pm 23.1)\end{array}$ & $\begin{array}{c}20.2 \\
( \pm 18.8)\end{array}$ & $\begin{array}{c}16.0 \\
( \pm 17.6)\end{array}$ & $\begin{array}{c}19.0 \\
( \pm 18.6)\end{array}$ \\
\hline $\begin{array}{c}\text { Mann- } \\
\text { Kendall } \\
\tau\end{array}$ & $\begin{array}{c}-0.14 \\
(\mathrm{P} \\
=0.13)\end{array}$ & $\begin{array}{c}0.11 \\
(\mathrm{P} \\
=0.26)\end{array}$ & $\begin{array}{c}0.16 \\
(\mathrm{P} \\
=0.04)\end{array}$ & $\begin{array}{c}-0.09 \\
(P=0.29)\end{array}$ & $\begin{array}{c}0.07 \\
(\mathrm{P}=0.40)\end{array}$ & $\begin{array}{c}-0.08 \\
(\mathrm{P}=0.40)\end{array}$ & $\begin{array}{c}0.14 \\
(\mathrm{P}=0.10)\end{array}$ & $\begin{array}{c}-0.09 \\
(\mathrm{P}=0.32)\end{array}$ & $\begin{array}{c}-0.05 \\
(\mathrm{P}=0.66)\end{array}$ & $\begin{array}{c}-0.14 \\
(\mathrm{P}=0.13)\end{array}$ & $\begin{array}{c}0.02 \\
(\mathrm{P}=0.81)\end{array}$ & $\begin{array}{c}0.06 \\
(\mathrm{P}=0.47)\end{array}$ & $\begin{array}{c}0.02 \\
(\mathrm{P}=0.59)\end{array}$ & $\begin{array}{c}-0.02 \\
(\mathrm{P}=0.71)\end{array}$ & $\begin{array}{c}0.01 \\
(\mathrm{P}=0.81)\end{array}$ \\
\hline
\end{tabular}


Table A4.3: Mean precipitation (mm) at Jambi airport meteorological station and results of Mann-Kendall test (Mann-Kendall $\tau$ and $p$-value) during the period 1978-2016.

\begin{tabular}{|c|c|c|c|c|c|c|c|c|c|c|c|c|c|c|c|}
\hline \multirow{2}{*}{ Year } & \multicolumn{12}{|c|}{ Month } & \multirow{2}{*}{$\begin{array}{c}\text { Wet } \\
\text { season } \\
\text { (Oct.- } \\
\text { May) }\end{array}$} & \multirow{2}{*}{$\begin{array}{c}\text { Dry } \\
\text { season } \\
\text { (Jun.- } \\
\text { Sept.) } \\
\end{array}$} & \multirow{2}{*}{ Annual } \\
\hline & Jan. & Feb. & Mar. & Apr. & May & Jun. & Jul. & Aug. & Sept. & Oct. & Nov. & Dec. & & & \\
\hline $\begin{array}{l}1978- \\
2016\end{array}$ & $\begin{array}{c}199.3 \\
( \pm 85.7)\end{array}$ & $\begin{array}{c}180.2 \\
( \pm 79.9)\end{array}$ & $\begin{array}{c}233.9 \\
( \pm 82.7)\end{array}$ & $\begin{array}{c}256.0 \\
( \pm 90.0)\end{array}$ & $\begin{array}{c}170.5 \\
( \pm 64.8)\end{array}$ & $\begin{array}{c}112.4 \\
( \pm 64.6)\end{array}$ & $\begin{array}{c}112.5 \\
( \pm 81.4)\end{array}$ & $\begin{array}{c}124.6 \\
( \pm 92.9)\end{array}$ & $\begin{array}{c}129.6 \\
( \pm 86.1)\end{array}$ & $\begin{array}{c}223.0 \\
( \pm 105.8)\end{array}$ & $\begin{array}{c}241.1 \\
( \pm 98.9)\end{array}$ & $\begin{array}{c}248.2 \\
( \pm 86.6)\end{array}$ & $\begin{array}{l}1798.2 \\
( \pm 91.6)\end{array}$ & $\begin{array}{c}491.7 \\
( \pm 81.4)\end{array}$ & $\begin{array}{l}2289.9 \\
( \pm 99.9)\end{array}$ \\
\hline $\begin{array}{l}\text { Mann- } \\
\text { Kendall } \\
\tau\end{array}$ & $\begin{array}{c}-0.28 \\
(\mathrm{P}=0.01)\end{array}$ & $\begin{array}{c}-0.08 \\
(\mathrm{P}=0.51)\end{array}$ & $\begin{array}{c}-0.02 \\
(\mathrm{P}=0.85)\end{array}$ & $\begin{array}{c}-0.22 \\
(\mathrm{P}=0.05)\end{array}$ & $\begin{array}{c}-0.12 \\
(\mathrm{P}=0.31)\end{array}$ & $\begin{array}{c}-0.08 \\
(\mathrm{P}=0.51)\end{array}$ & $\begin{array}{c}0.16 \\
(\mathrm{P}=0.16)\end{array}$ & $\begin{array}{c}0.10 \\
(\mathrm{P}=0.38)\end{array}$ & $\begin{array}{c}-0.16 \\
(\mathrm{P}=0.16)\end{array}$ & $\begin{array}{c}-0.13 \\
(\mathrm{P}=0.24)\end{array}$ & $\begin{array}{c}-0.06 \\
(\mathrm{P}=0.63)\end{array}$ & $\begin{array}{c}0.02 \\
(\mathrm{P}=0.85)\end{array}$ & $\begin{array}{c}0.09 \\
(\mathrm{P}=0.02)\end{array}$ & $\begin{array}{c}0.03 \\
(\mathrm{P}=0.54)\end{array}$ & $\begin{array}{c}-0.05 \\
(\mathrm{P}=0.10)\end{array}$ \\
\hline
\end{tabular}

Table A4.4: Average precipitation intensity index ( \pm standard deviation) at Jambi Airport meteorological station and results of Mann-Kendall test (Mann-Kendall $\tau$ and $p$-value).

\begin{tabular}{|c|c|c|c|c|c|c|c|c|c|c|c|c|c|c|c|}
\hline \multirow{2}{*}{ Year } & \multicolumn{12}{|c|}{ Month } & \multirow{2}{*}{$\begin{array}{c}\text { Wet } \\
\text { season } \\
\text { (Oct.- } \\
\text { May) } \\
\end{array}$} & \multirow{2}{*}{$\begin{array}{c}\text { Dry } \\
\text { season } \\
\text { (Jun.- } \\
\text { Sept.) } \\
\end{array}$} & \multirow[t]{2}{*}{ Annual } \\
\hline & Jan. & Feb. & Mar. & Apr. & May & Jun. & Jul. & Aug. & Sept. & Oct. & Nov. & Dec. & & & \\
\hline $\begin{array}{l}1991- \\
2016\end{array}$ & $\begin{array}{c}11.3 \\
( \pm 11.9)\end{array}$ & $\begin{array}{c}13.1 \\
( \pm 13.4)\end{array}$ & $\begin{array}{c}16.1 \\
( \pm 16.6)\end{array}$ & $\begin{array}{c}14.2 \\
( \pm 14.2)\end{array}$ & $\begin{array}{c}12.8 \\
( \pm 12.8)\end{array}$ & $\begin{array}{c}11.9 \\
( \pm 14.6)\end{array}$ & $\begin{array}{c}15.3 \\
( \pm 18.2)\end{array}$ & $\begin{array}{c}13.7 \\
( \pm 15.5)\end{array}$ & $\begin{array}{c}11.1 \\
( \pm 12.0)\end{array}$ & $\begin{array}{c}14.7 \\
( \pm 12.4)\end{array}$ & $\begin{array}{c}14.4 \\
( \pm 13.0)\end{array}$ & $\begin{array}{c}15.7 \\
( \pm 15.0)\end{array}$ & $\begin{array}{c}14.0 \\
( \pm 13.8)\end{array}$ & $\begin{array}{c}13.0 \\
( \pm 15.2)\end{array}$ & $\begin{array}{c}13.8 \\
( \pm 14.2)\end{array}$ \\
\hline $\begin{array}{c}\text { Mann- } \\
\text { Kendall } \\
\tau\end{array}$ & $\begin{array}{c}-0.01 \\
(\mathrm{P}=0.79)\end{array}$ & $\begin{array}{c}0.05 \\
(\mathrm{P}=0.34)\end{array}$ & $\begin{array}{c}-0.13 \\
(\mathrm{P}<0.01)\end{array}$ & $\begin{array}{c}0.02 \\
(\mathrm{P}=0.74)\end{array}$ & $\begin{array}{c}-0.03 \\
(\mathrm{P}=0.54)\end{array}$ & $\begin{array}{c}-0.08 \\
(\mathrm{P}=0.18)\end{array}$ & $\begin{array}{c}-0.04 \\
(\mathrm{P}=0.54)\end{array}$ & $\begin{array}{c}0.01 \\
(\mathrm{P}=0.92)\end{array}$ & $\begin{array}{c}-0.05 \\
(\mathrm{P}=0.44)\end{array}$ & $\begin{array}{c}-0.03 \\
(\mathrm{P}=0.57)\end{array}$ & $\begin{array}{c}-0.05 \\
(\mathrm{P}=0.36)\end{array}$ & $\begin{array}{c}-0.03 \\
(\mathrm{P}=0.56)\end{array}$ & $\begin{array}{c}0.05 \\
(\mathrm{P} \\
=0.01)\end{array}$ & $\begin{array}{c}0.0 \\
(\mathrm{P} \\
=0.96)\end{array}$ & $\begin{array}{c}-0.03 \\
(\mathrm{P}=0.06)\end{array}$ \\
\hline
\end{tabular}


Appendix 5: Accuracy statistics of land use/cover classes

Table A5.1: Accuracy statistics and area proportion of each land use/cover class in the Tembesi watershed for the year 2013 (recalculated from Melati 2017).

\begin{tabular}{|c|c|c|c|c|c|}
\hline \multirow{2}{*}{$\begin{array}{l}\text { Land use/ cover } \\
\text { class }\end{array}$} & \multicolumn{3}{|c|}{ Accuracy } & \multicolumn{2}{|c|}{$\begin{array}{c}\text { Area proportion } \\
(\%)\end{array}$} \\
\hline & User's & Producer's & Overall & Map & Estimated \\
\hline Agriculture & $\begin{array}{r}72.4 \pm \\
16.6\end{array}$ & $95.6 \pm 5.4$ & \multirow{7}{*}{$\begin{array}{r}85.8 \pm \\
4.4\end{array}$} & 16.3 & $\begin{array}{r}12.4 \pm \\
2.8\end{array}$ \\
\hline Bush/bareland & $\begin{array}{r}79.4 \pm \\
10.1 \\
\end{array}$ & $\begin{array}{r}60.3 \pm \\
17.4\end{array}$ & & 7.1 & $9.4 \pm 2.8$ \\
\hline Forest & $93.9 \pm 6.8$ & $95.4 \pm 3.2$ & & 38.1 & $\begin{array}{r}37.5 \pm \\
2.9 \\
\end{array}$ \\
\hline Oil palm & $83.3 \pm 10$ & $\begin{array}{r}68.5 \pm \\
13.8 \\
\end{array}$ & & 10.8 & $\begin{array}{r}13.1 \pm \\
2.8 \\
\end{array}$ \\
\hline Rubber & $86.4 \pm 7.5$ & $90.9 \pm 6.7$ & & 25.6 & $\begin{array}{r}24.4 \pm \\
2.6 \\
\end{array}$ \\
\hline Settlement & $\begin{array}{r}81.3 \pm \\
19.8\end{array}$ & $\begin{array}{r}35.2 \pm \\
22.3\end{array}$ & & 1.3 & $2.9 \pm 1.8$ \\
\hline Water body & $50 \pm 43.8$ & $100 \pm 0$ & & 0.8 & $0.4 \pm 0.3$ \\
\hline
\end{tabular}

